\title{
THE EU PUZZLING CSR REGIME AND THE CONFUSED PERCEPTION BY AMBASSADORS OF LUXURY FASHION BUSINESSES: A CASE STUDY FROM PAŘIIŽSKÁ
}

\section{MacGregor Pelikánová, R., MacGregor, R.K.}

Radka MacGregor Pelikánová / International Business Department, Metropolitan University Prague, Dubečská 900/10, Prague 10, Czech Republic. Email: radkamacgregor@yahoo.com.

Robert K. MacGregor / International Business Department, Metropolitan University Prague, Dubečská 900/10, Prague 10, Czech Republic. Email: robertkmacgregor@yahoo.com.

\begin{abstract}
Despite a decades-long discussion about corporate social responsibility ("CSR"), there is little known about the evolution and meaning of the EU law on CSR and its perception by various stakeholders. The two objectives of this paper are: (i) assessing the evolution to the current EU law on CSR and (ii) making a case study about the perception of CSR by businesses from the luxury fashion industry supposed to be the leading CSR force, namely their ambassadors - CEOs and employees facing the clientele in Pařižská street in Prague. In order to address these two objectives, holistic and interdisciplinary research of economic, legislative and academic sources as well as a case study, entailing interviews and mystery shopping was performed. The exploration of the yielded data employed Meta-Analysis, content analysis, teleological interpretation, etc. The critical and comparative review of the evolution of the EU law on CSR shows piecemeal trends and a lack of permanent consent. This leads to the fragmentation and ambiguity, which is matched by the findings of the case study. The perception of the EU law on CSR is done differently by various CEOs of luxury fashion businesses, and there is an inconsistency between their attitudes and those of their employees facing the clientele. Such inconsistency undermines the effectiveness and efficiency of the CSR regime and needs to be corrected. ${ }^{1}$

Implications for Central European audience: Although the sustainability projected in CSR is critical, the EU law has undergone a complex and fragmented evolution leading to a partially mandatory framework. The understanding and application of such a framework about CSR and its reporting is a challenge. A Central European case study of luxury fashion industry businesses shows piecemeal trends and a lack of consent, and this even among CEOs and frontline employees of the same business. The implication of such an inconsistency is a decrease in the effectiveness and efficiency of the CSR regime, a devaluation of the CSR awareness and the need for corrections.
\end{abstract}

Keywords: corporate social responsibility (CSR); EU law; luxury industry JEL Classification: K20, M14, Q01

${ }_{1}^{1}$ An earlier version of a part of this paper has been presented at the 7th International Conference Innovation, Management, Enterpreneurship and Sustainability (IMES) in Prague, May 30, 2019. 


\section{Introduction}

The economic globalization has led to a dramatic increase in productivity linked to negative externalities, such as social and ecologic damages (Schüz, 2012). In 1945, the United Nations ("UN ") was founded as an international organization, and already in 1948, the UN General Assembly proclaimed in Paris the Universal Declaration of Human Rights ("UDHR"). The UDHR is accepted as a customary international law which deals with human rights principles, such as the duty to the community, the right to material and moral interests in one's creative work, the right to freedom of expression, the right to participate in cultural life and the right to health (MacGregor Pelikánová, 2019e). Around 1970, this inspired the emergence of the concept of sustainability based on environmental, social and economic pillars and focusing on the reconciliation of available resources as an increasing world population emerged (Meadows et al., 1972). This concept of sustainability became immediately linked to value judgments about justice in the distribution and use of resources (Marinova \& Raven, 2006). Top concerns entailed the balance of the sustainable development, available resources and increased population needs (Jindřichovská \& Purcarea, 2011), i.e. how to achieve long-term continuity (Marinova \& Raven, 2006). Therefore, the concept of sustainability is the outcome of the reconciliation of the needs of the current generation and the ability of future generations to meet their needs and is conventionally represented as a three pillars project unifying economic (profit), environmental (planet) and social (people) dimensions. It was incorporated in international law by three key instruments representing the inspiration, if not directly the foundation, for the EU law and EU member state's laws. As expected, behind both of them was the UN which raised the burning questions how to achieve global prosperity without environmental deterioration in the world (Jindřichovská \& Purcarea, 2011), in both developed and developing countries (MacGregor Pelikánová, 2019a).

The first instrument was the Report of the World Commission on Environment and Development Report: Our Common Future prepared by the Brundtland Commission (WCED, 1987), published as the UN Annex to document A/42/427 in 1987 ("Brundtland Report 1987") (MacGregor Pelikánová, 2018a). The Brundtland Commission indicates that... "Sustainable development is the development that meets the needs of the present without compromising the ability of future generations to meet their own needs." Consequently, it is proposed that the concept of sustainability is analogous to the concept of usufructus, i.e. the right to use another's a property without changing its substance, extended beyond the economic realm to cover social and environmental aspects of human activities (Anand \& Sen, 2000).

The second instrument was the UN General Assembly resolution A/RES/60/1 adopted via World Summit 2005 ("UN Resolution 2005") along with UN Agenda 21, which were paralleled by the EU strategy Agenda 2000 aka Lisbon Agenda 2000 and later on the strategy Europe 2020. (MacGregor Pelikánová, 2018b).

The third instrument was the Resolution made during a historic UN Summit in September 2015 and entitled 'Transforming our world: the 2030 Agenda for Sustainable development' ("UN Agenda 2030"), which brought with it 17 Sustainable Development Goals ("SDGs") and 169 associated targets and was adopted by world leaders (MacGregor Pelikánová, 2018c). Importantly, the SDG 9 deals with decent work and economic growth, SDG 9 means to build resilient infrastructures, promote inclusive and sustainable industrialization and foster 
innovation, including the increase of the IS/IT and affordable access to the Internet (Turečková, 2016), and SDG 12 wants to ensure sustainable consumption and production patterns (Olšanová et al., 2018). Clearly, the UN Agenda 2030 with the SDG 9 reacts to this pragmatic economic fear regarding the decrease of the global competitiveness of the EU as well as the sustainability and social dimension (Pakšiová, 2016). In January 2016, these SDGs became universally applicable in order to mobilize efforts and to stimulate action towards them for the next 15 years, i.e. until 2030 (MacGregor Pelikánová, 2018c). However, it must be emphasized that these three key instruments, along with SDGs, are the outcome of the International Law and are not per se enforceable. Therefore, it is up to states whether they embody them in their legal systems or not (MacGregor Pelikánová, 2018a). Therefore, the classic international law subjects, states and government organizations, have to consider them while shaping their national laws and naturally they demonstrate different levels and intensities in their commitments. Unless mandatory provisions are made within national laws, businesses are free to observe or not observe it.

The initial focus on sustainability has been progressively paralleled by corporate responsibility concerns (MacGregor Pelikánová, 2019a), while trying to support certain types of social behaviour, such as altruistic behaviour, i.e. behaviour defined as sacrificing one's resources to benefit others without expecting an external reward (Bar-Tal, 1986) and supporting humanity's collective corporation and social development (Fehr \& Fischbacher, 2016). Namely, the original distinction between (i) sustainability in the narrow sense, with rather systematic and visionary features and designed for soft law and self-regulation, and (ii) corporate responsibility, with rather normative and moral features and designed for national law regulation, have converged in the CSR (Bansal \& Song, 2017).

The concept of sustainability and CSR are critical for the global society, and the EU is aware of it. Modern European integration is based upon the doctrine of the famous four freedoms of movement in the single internal market, and strategic priorities for 2010-2020 are proclaimed in Europe 2020: A strategy for smart, sustainable and inclusive growth ("Europe 2020") (MacGregor Pelikánová, 2017a). Europe 2020 was issued in the aftermath of crises in 2007 and 2008 (MacGregor Pelikánová \& Beneš, 2017) to address chronic deficiencies (Balcerzak, 2015), including aspects of the failed Lisbon Strategy and shortcomings in financial regulation and management responsibilities in corporate governance (Bavoso, 2012). Europe 2020 entails the CSR demands, see the Green Paper: Promoting a European Framework for CSR (Matuszak \& Róźanska, 2017). Pursuant to Europe 2020, the CSR represents a transparent dialogue and interaction between businesses and other stakeholders which should be materialized, among others, by publicly available financial reporting and non-financial reporting, aka CSR reporting (Matuszak \& Róźanska, 2017). Thus, for the EU and EU member states, the sustainability in the large sense represents a current multi-stakeholder relationship of virtually all members of society and even the society itself (Pakšiová, 2017), and the resulting CSR is only partially covered by mandatory EU and national law provisions. Hence, the accountability of EU businesses with respect to sustainability is fragmentally regulated by constantly evolving EU laws and national laws (Jindřichovská \& Purcarea, 2011).

The CSR Progress and satisfaction of SDGs is supposed to be led by developed countries and prominent global industries (Olšanová et al., 2018). There are extensive studies about the (lack of) progress by automotive (MacGregor Pelikánová, 2019a), food (Haski-Leventhal, 
2018; Pakšiová \& Lovciová, 2019), tobacco (Chandler, 2017) and other industries (Sroka \& Szántó, 2018). Manifestly, the luxury fashion industry in the EU should belong to them and indeed might be expected to be the leading CSR force. For luxury fashion businesses, the key values and competitive advantage determinants are linked to their luxury brands protected as trademarks (MacGregor Pelikánová \& MacGregor, 2019) and other Intellectual Property ("IP ") assets (MacGregor Pelikánová, 2019c). Such brands represent scarcity, exclusivity and overflow resources used for top goals and priorities, such CSR. So, they desperately need to come across as being for CSR and also as able to afford CSR, at least based on expectations of their customers (Olšanová et al., 2018) and their potential investors (Morgan Stanley, 2017). However, is this a mere speculation or a well-founded expectation or even reality? Well, in order to address these burning questions, it must be plainly figured out what is strictly required by the mandatory legal framework and what is left to be shaped by the inside attitude of the ambassadors of these businesses, i.e. their agents de facto. If they are aware and committed in a unified manner to CSR, then such a CSR fully conforming attitude can even bridge fragmentations and oscillation between mandatory and facultative regimes of EU and national laws about CSR. Therefore, it is pivotal to explore via a pioneering Czech case study the perception of CSR by CEOs and CEOs and employees of these luxury fashion businesses facing the clientele in Pařižská street in Prague.

\section{Literature Review}

Both the concept of sustainability and CSR have grown with globalization and the apparently unrestricted growth in the power of corporations leading to the proposition that global companies, as powerful economic, social and political actors, must increasingly be brought within the law's domain (Bunn, 2004). They have been confronted with positive as well as negative influences (MacGregor Pelikánová, 2019a; Petera et al., 2019). Indeed, a myriad of meta-analytic, horizontal and vertical studies have shown (i) that human's concern for others has rather decreased during the last decades (Konrath, 2011; MacGregor Pelikánová, 2019b) and (ii) that more altruism and sustainability awareness and commitment is exhibited by responsible people, i.e. the positive attitude towards CSR often co-relates with the positive attitude to the responsibility duty (Peterson, 1983). However, the concept of sustainability and CSR should involve each and every subject, and, thus, they could hardly be left to the free consideration of all stakeholders (MacGregor Pelikánová, 2019a). Consequently, the increasing interest in them has been accompanied by various soft and hard law incentives, i.e. regulatory efforts attempting to set minimum standards and the publication duty (Peterson, 1983).

CSR means the responsibility towards all stakeholders aka the entire society, including owners and investors, and so the word "social" does not mean that CSR is reduced only to one sustainability pillar, i.e. social dimension, but instead that CSR is about the allencompassing responsibility towards the society, i.e. addressing all three sustainability pillars (Olšanová et al., 2018) and even fair competition (Albu et al., 2013; MacGregor Pelikánová, 2019b, MacGregor Pelikánová, 2019d). Consequently, the CSR principles are a demonstration of moral obligations of the given business towards the entire society, and this goes way beyond the mere concept of profit maximization (Berman et al., 1999). CSR is the business's commitment to maximize long-term (!) economic, social and environmental wellbeing through business practices, policies and resources (Olšanová et al., 2018). Arguably, the essential goals of CSR are to protect human rights, to respect human rights, and to 
remedy human rights violations (Osei-Tutu, 2019). Basically, CSR protects social interests to redistribute to the society, i.e. to share in the long term. As a matter of fact, CSR vis-à-vis employees and employment is a perfect example of the overlapping three pillars of sustainability, because it can reduce unemployment (Tvrdoň, 2016), improve economic performance (Tvrdoň et al., 2012) and profit the entire society.

The CSR consists of many types of social responsibility: economic, legal, ethical, etc. (Sroka \& Szántó, 2018), i.e. it is a set of duties to adhere to in a certain manner because it is either morally or legally right or at least expected (MacGregor Pelikánová, 2019e). Responsibility as such has Latin roots, see "respondere", and means that someone has to answer for effects caused by him to authority, and this authority evaluates its damages (Schüz, 2012). If this regime is incorporated into the legal system, and this authority is a judge, we deal with a special type of responsibility called liability. Indeed, Christianity and Roman law have significantly shaped the current understanding of the individual and collective triad: accountability - responsibility - liability (MacGregor Pelikánová, 2017c). CSR means that businesses competing in the marketplace are accountable to a very large spectrum of stakeholders, i.e. to society (Jindřichovská \& Purcarea, 2011), and this accountability is not fully enforceable by the law (otherwise we would speak about corporate social liability). Indeed, the CSR emerged originally rather as an "ethical responsibility" than "legal liability" and represented virtue ethics, utilitarian ethics and deontological ethics (Schüz, 2012). States have demonstrated various approaches to sustainability and accordingly have "delegated" some CSR tasks and duties to stakeholders, including businesses (MacGregor Pelikánová, 2019a). Therefore, the CSR goes through a process of progression from no regime over a facultative regime to a mandatory regime (MacGregor Pelikánová, 2019e; Strouhal et al., 2016).

Even businesses do not exhibit a unified trend, i.e. for some, their commitment to the sustainability via CSR is a mere imposed duty and negative burden, while for other businesses CSR is a vehicle for improvement in all three spheres of sustainability (economic, environmental and social) and an instrument to improve their own financial performance (Rodriguez-Fernandez, 2016). Allegedly, for some businesses, the CSR is just a developed form of charity or adherence to theories of business ethics, while, for other businesses, it is rather a voluntary engagement in best global practices. The ability to address economic, environmental and social issues, i.e. to address the sustainability of the global society turned into the CSR of a business (Křečková Kroupová, 2015) while contributing to profit maximization, represents the recognition of shared value policies and principles and aims to "a more sophisticated form of capitalism "(Porter \& Kramer, 2011). Consequently, the originally simplistic CSR becomes strategic CSR, and the evolution phases are CSR cultural reluctance, CSR cultural grasp and CSR cultural embedment (Olšanová et al., 2018). A prevailing modern trend suggests that businesses are involved in the integration of economic, environmental (Polcyn et al., 2019), and social objectives in various functional areas (Ting et al., 2019) and often advertise their CSR endeavours and publish reports about their CSR accomplishments (Zhao et al., 2018). Conventional economic studies and searches point to the rational drive of humans to go for utility maximization, while psychological and social studies and searches suggest that humans, and their behaviour as well, are socially (Diekhof et al., 2014) and sustainably oriented (Hochman et al., 2015). Certain theoretical models on CSR point to the co-relations of the involved objectives and suggest that the satisfaction of expectations of various stakeholders may increase financial performance (Preston \& 
O'Bannon, 1997). On the one hand, the stakeholder theory proposes that the business engagement with CSR implies (at least indirectly) the value creation, improvement of the business reputation (Gallardo-Vázquez et al., 2019) and branding (Osei-Tutu, 2019) and ultimately the increase of market share (Ting et al., 2019). On the other hand, traditional theories are more sceptical, point to limitations due to possible agency conflicts between managers, shareholders, environment activists, etc. (Strouhal et al., 2015) and underline that resource allocation due to the CSR, especially for social goals, may add to the costs and consequently prevents profit maximization (Friedman, 2007), and consequently, businesses should not automatically jump to the conclusion that more CSR and more CSR reporting has to lead to the ultimate and global success. Several studies documented the negative impact of CSR activities and spending by indicating that CSR practices can generate unnecessary costs, cripple financial results (Barnett, 2007) and thus undermine the competitive advantage (Scherer \& Palazzo, 2011).

Regardless of all these discourses, all modern businesses need to reconcile the profitability, growth and social relationships, i.e. CSR cannot be totally avoided and, according to the prevailing opinion stream, it positively impacts financial performance (Ting et al., 2019). Further, the law is making it compulsory for certain (larger and critical) businesses to prepare and publish their CSR, and often even other businesses do so. However, again, various trends and intensities of commitment are to observed (MacGregor Pelikánová, 2019a). The current management literature proposes as major factors influencing the extent of CSR reporting: profitability, size, financial leverage, market-to-book value, liquidity and ownership structure (Andrikopoulos et al., 2014). Currently, almost all multinational companies declare their CSR and report about it (Gillai et al., 2014). CSR can be a tool bridging the public concern and the corporate worlds, and providing a business with a theoretical and practical legitimacy tool to follow treaties, standards or norms which may not be applicable or enforceable in respect to them (Bunn, 2004). CSR reporting may decrease information asymmetry and arguably even lead to a reduction in the cost of debt (Goss \& Roberts, 2011).

Ultimately, the CSR should serve all stakeholder's interests and even enhance financial performance (Rowley \& Berman, 2000) and so businesses should proudly publish their financial and non-financial reports, even if this is often not compulsory, and enjoy their mutual support. However, the verb "should "must so far be used, i.e. a firm direct link between CSR reporting and business financial performance has not yet been fully established (Strouhal et al., 2015). However, it is not only about the quantity (to do any CSR or to do some reports about that), it is about the quality (what kind of CSR is done and reported). As the society becomes more and more concerned about ethical (Sroka \& Szántó, 2018), social (Mallin, 2018) and environmental (Krause, 2015) issues, appropriate, reasonable and well oriented CSR "expenses "should be compensated, offset, by the advertising effect of an improved brand image, stable revenues from loyal clients, improved employee productivity (Ikram et al., 2019), decreased risks (Sharfman \& Fernando, 2008) and reduced capital costs (Galbreath, 2013). It might be proposed that this fine balance mechanism needs to be set and operated effectively and efficiently, i.e. the public-at-large needs to learn about the correctly set and applied CSR of the given business. Indeed, businesses might find that, for them, properly tailored CSR practices are cost-effective (Osei-Tutu, 2019).

This can be achieved only if businesses select CSR activities matching the expectations and/or active approval of other stakeholders and these stakeholders learn about it, e.g. via 
reportage linked to all three pillars of the sustainability and translated into these six CSR categories (MacGregor Pelikánová, 2019a):

- $\quad$ environment protection (Krause, 2015),

- $\quad$ employee matters (Dvouletý, 2017; Ikram et al., 2019; Křečková Kroupová, 2015),

- $\quad$ social matters and community concerns (Mallin, 2018),

- $\quad$ respect for human rights (Osei-Tutu, 2019),

- $\quad$ anti-corruption and bribery matters (Sroka \& Szántó, 2018) and

- $\quad$ R\&D activities (MacGregor Pelikánová, 2019c).

This proposition is supported by the evidence that CSR reporting significantly impacts a firm's value (El Ghoul et al., 2011) and that especially R\&D spending has a noticeable potential to boost the productivity and ultimately lead to product differentiation and entry barriers (McWilliams \& Siegel, 2000). Arguably, such a correlation could be established, at least to a certain extent, as well with respect to other, more social, CSR categories. Social relations could bring many advantages for a business, such as employee stability aka human resources retention, improvement of local community relationships and even the attraction of social and ethical investors and customers (Bhattacharya \& Sen, 2004).

The most critical determinant of sustainability and ultimately of (any category of) CSR is the genuine quality of a business' relationship, engagement with all stakeholders (Ting et al., 2019) and effective and efficient reporting about that (MacGregor Pelikánová, 2019a). The study based on the Forbes list of "100 best CSR companies in the world "documented the positive interaction and mutual support of the economic (business performance) pillar and environmental and social pillar (Ting et al., 2019), i.e. businesses recognizing all three sustainability pillars and engaging in a genuine CSR are more likely to have positive earnings than firms with bad social and environmental performance (Li et al., 2019). Ambassadors of businesses are their top managers and employee in direct interaction with other stakeholders, such as business partners and customers, and it is well argued that just motivated and retained employees become one of the most important business's assets and a substantial point of difference from the competition (Němečková, 2013). They are either de iure and/or de facto agents of the business and they carry its inside CSR attitude and transform it in tangible actions towards the outside.

The fashion luxury industry was traditionally linked to the allure of limited access, heritage, sophistication, high desirability, excellent quality, high price and the extra-ordinary (Dubois \& Paternault, 1995; Olšanová et al., 2018). Luxury brands sell products that are rare, and this should increase the need for sustainability (Kale \& Öztürk, 2016; Olšanová et al., 2018) and via trademarks are top assets (MacGregor Pelikánová, 2017a; MacGregor Pelikánová \& MacGregor, 2019). Indeed, historically, the luxury industry has been associated with concepts like excessive consumerism, extremely high costs, elitism, opulency or guilty pleasures (Deloitte, 2019). However, recently, it seems that two new luxury fashion customer groups have appeared - the HENRYs (High-Earners-Not-Rich-Yet) and youngsters (Millennials and Gen Z) (Deloitte, 2019). Customers from both these groups master information systems and information technologies (IS/IT), look for an individualized, seamless brand relationship, rely on social media, but do not hesitate to make their own Internet research or to physically go and check brick and mortar shops. Luxury fashion businesses are located in one particular street and in the case of the Czech Republic, it is Pařižská street in Prague. Therefore, customers from these two groups, and perhaps even other customers, 
check online CSR reports as well CSR direct manifestation in these shops and search for a demonstration of "their "ethic and moral values - such as transparency, environment sustainability (eco-system friendliness), animal welfare, production and labour practices, the positive impact on communities all these elements are now taken into consideration when buying a product, and luxury goods and ethical standards (Deloitte, 2019).

Since the concept of sustainability and CSR might be a key to maintain the current customers and especially to gain new customers (Deloitte, 2019) and both the society in general and law demand transparent public information about CSR, a demonstration of CSR via CSR reports and statements issued by CEOs, as well as the attitude of employees dealing directly with customers, is critical. A positive and committed perception of CSR by luxury fashion ambassadors--as shown by CEOs and floor employees-- can lead to a competitive advantage. At the same time, only motivated and committed employees lead to satisfied business partners and customers (Křečková Kroupová, 2015) and ultimately actively participate in the advancement of CSR and information about it. Therefore, it can be argued that the pre-requirement of an effective and efficient CSR with ultimately a positive impact on financial results, is the enhancement of awareness and engagement of both top management and employees. To put it another way, CSR efforts seem futile if they are not genuine, not transparently communicated or poorly oriented (MacGregor Pelikánová, 2019a). Boldly, CSR endeavours vis-a-vis stakeholders at large could hardly flourish if these business ambassadors are not interested in CSR, if stakeholders are not informed about the CSR of the business or if CSR initiatives and expenses do not meet the CSR expectations or preferences of stakeholders. In such a situation, there is no way to move away from the CSR cultural reluctance phase toward CSR cultural grasp and CSR cultural embedment phases (Olšanová et al., 2018).

\section{Data and Methods}

The data and methods used in this paper are determined by its two mutually related objectives: (i) assessing the evolution to the current EU law on CSR and (ii) making a case study about the perception of CSR by businesses from the luxury fashion industry supposed to be the leading CSR force, especially their ambassadors--CEOs and employees facing the clientele in Pařížská street in Prague. Namely, it needs to be appreciated what is required, based on the dynamic and complex legal evolution, and what perception of CSR is within such a framework, expressed by stakeholders who are either de iure (CEOs) or de facto (employees facing the clients) ambassadors of luxury fashion businesses. Boldly, (i) the understanding of the normative evolution and implied current legal setting is an indispensable pre-requirement to move to (ii) the case study regarding its application from the perspective of a pre-defined group of stakeholders. Clearly, it must be set in an unambiguous manner: what is a must and what is left for consideration. These two research objectives are addressed based upon a multi-disciplinary as well as multi-jurisdiction research of primary and secondary data and the processing of such by methods that are both critical and comparative. The focus on the luxury fashion industry allows for working with a homogenous and inclusive sample where data can be collected from and regarding each and every business, and therefore the relevancy is high despite a low number of these businesses. The studied materials can be classified into five principal categories:

- political, legislative and semi-legislative documents generated by state authorities, which are accessible from EurLex, Curia, and other state databases; 
- $\quad$ academic writings which are accessible from WoS and Scopus database;

- $\quad$ internal business documents generated by businesses themselves, such as reports and www postings which are accessible from eJustice and www sites of businesses;

- comparative scoring documents generated by semi-official reviewers of the CSR and other official and semi-official indexes which are available from www sites of pertinent agencies and institutions;

- $\quad$ own elaborated documents based on interviews and mystery shopping experiences which were made by the Authors based on their field search in December 2019.

Neither research methods nor research problems are neutral, and methods should be our servants, not our rulers - methods are properly used as tools when they are genuinely needed (Silverman, 2013). The interpretation, methodological processing and assessment of information obtained from the above-indicated sources will be determined by the fundamental task in all areas of science - the development of theory and theoretical concepts, the production of cumulative knowledge (Schmidt \& Hunter, 2014) and the modelling of a phenomenon at a deeper level. (Heckman, 2005a). Simultaneously, knowledge of a field and the relevant processes that are available includes a set of exogenous predictors indicated by theory, as well as the relative spatial positioning of the observations in the given setting (Bhati, 2005). The common law perspectives with their pragmatic attitudes are matched with continental law perspectives with their theoretical attitude (MacGregor Pelikánová, 2019d). Regarding the dilemma between the qualitative and quantitative approach and analysis, it must be underscored that they are not contradictory and exclusive, rather they are complementary (MacGregor Pelikánová, 2018a), and as such will be employed. Quantitative analysis and instruments that are based on statistic science are instructive, but often they're concentrating upon the effort "to make it as objective as possible" leads to a negative experience, misleading results blindly attached to the "numeric" facts (Heckman, 2005a) and other inherent deficiencies (Heckman, 2005b). Thus the predisposition towards choosing "subjective "qualitative methods comes about (Silverman, 2013). However, this does not mean that qualitative methods are intrinsically superior and that quantitative methods should be avoided, not at all (Silverman, 2013). Instead, it points to the Meta-Analysis, which is an analysis of analyses (Schmidt \& Hunter, 2014) and which is a quasi-statistical analysis of a large collection of results from individual studies with the goal to integrate their findings (Glass, 1976). Meta-Analysis is founded upon the conviction that there was discovered more than what was understood. Meta-Analysis focuses on contrasting, combining and reconciling data, and the results from different studies in order to identify patterns, relations, and relationships are undoubtedly very highly relevant for the study of domain names and their significance (MacGregor Pelikánová, 2018a). In particular, Meta-Analysis is pivotal for the assessment of the discussed case study, because it addresses the results of studies dealing with direct and implied information and feedback, reconciles the juxtaposition of automatic scan content analysis (number of pages and keyword frequency) and manual Delphi content analysis (ranking read information) and reduces the degree of error and misunderstanding. Indeed, Meta-Analysis is a rigorous alternative to the casual, narrative discussions of research studies which typify efforts to make sense of the swiftly expanding research literature (Glass, 1976). Due to the focus of this paper on the economic and legal perspectives, the qualitative analysis prevails over the quantitative but does not eliminate it. Along with the qualitative analyses, such as the qualitative text analysis (Kuckartz, 2014), 
which are inherently inclined to subjectiveness and needs to be boosted by the Delphi method and refreshed by glossing and Socratic questioning (Areeda, 1996), other more quantitative methods are employed.

In order to address the $1^{\text {st }}$ objective, i.e. assessing the evolution to the current EU law on CSR, the obvious key sources are the EurLex database, and Curia database and the top interpretation method must be based on the teleological approach due to the EU law nature, with refreshing Socratic critical comments and glosses. Due to the law dimension, one needs to pay attention to both deductive and inductive aspects of legal thinking (Matejka, 2013), because legal theoretic orientation reflects the legal science which is argumentative rather than axiomatic (Knapp, 1995). The process of what is known as legal thinking relies on the distinction of questions of law from questions of fact, the subsumption of fact findings with respect to a legal norm, mastering of syllogisms, and specific arguing (Knapp \& Gerloch, 2012). The argumentation itself must be not only rational, but also ethical, and it must mirror the concept of scientific modesty (Knapp, 2003), which naturally is not in contradiction, at variance, with the requirements of scientific courage and honesty (MacGregor Pelikánová, 2018b). Regarding the interpretation of the involved predominantly EU political, legislative and semi-legislative documents, the battery of instruments will entail a teleological and purposive approach. The teleological method of interpretation plays a key role in the interpretation and application of the EU law for multivarious reasons, including the fact that the Treaties involved, such as the TEU and TFEU, are imbued with teleology (Lenaerts \& Guttiérez-Fons, 2013). Consequently, without knowing the purpose, there is no interpretation approach that can lead to a satisfactory result, and this is true even for the regulation assigned to the sustainability and CSR (MacGregor et al., 2017). Further, the addressing of the $1^{\text {st }}$ objective demands the engagement with academic writings, especially from WoS and Scopus databases, their comparison and critical glossing. The solution and Resolution of conflicting principles and values should ultimately depend upon the axiological distinction between good and bad, and we need to improve our methods for synthesizing and integrating sources and data, especially concerning the research literature (Schmidt \& Hunter, 2014). All this, considered dynamically in its evolutionary context, should lead to the determination of the mandatory dimensions of the CSR and CSR reporting by businesses in the EU. In addition, this should create the foundation for a better appreciation of the $2^{\text {nd }}$ objective of this paper.

The $2^{\text {nd }}$ objective calls for making a case study about the perception of CSR by businesses from the luxury fashion industry, purported to be the leading CSR force, namely their ambassadors - CEOs and employees facing the clientele in Pařižská street in Prague. The case study method in this setting is highly relevant because it allows the Authors as investigators to retain the holistic and meaningful characteristics of real-life events (Yin, 2008). The case study conducted by the Authors had obvious parameters - businesses located in the Prague "Luxury Fashion Street aka Prague's $5^{\text {th }}$ Avenue ", using luxury brands (Dubois \& Paternault, 1995) and offering handbags, which are considered indicators and/or the "engine that drives luxury brands today "(Han et al., 2010). The perception of the CSR of ambassadors of these businesses was examined - CEOs based on their reports and employees facing the clientele based on their direct and indirect feedback obtained via interviews and mystery shopping observation. The mystery shopping was performed in a conventional manner mirroring common consumer behaviour (Osterweil, 2012) and aimed at gathering information before an anticipated purchase of a common product of the segment, 
i.e. a product offered and frequently sold by all businesses in the segment - a women's leather handbag size A4. Naturally, for the understanding of CEOs, official documents issued and signed by them were the key source calling for content analysis. The used content analysis (Kuckartz, 2014) entailed both - a quantitative approach based on scanning pages and working with keyword frequency (how many times a keyword - label word of each of the 6 CSR categories was used) and qualitative, based on a manual reading of all these documents and coding/ranking the CSR information about all 6 CSR categories by three experts, i.e. upgrading the previously used rather subjective four-point scaling (Kašparová, 2018) by a simplified Delphi analysis (MacGregor Pelikánová, 2019a). Table 1 summarizes the key elements of the case study.

Table 1 | Case Study - Ten luxury fashion businesses and their case study parameters

\begin{tabular}{|c|c|c|c|c|c|c|c|}
\hline & Origin & Group & Address & Domain & Report & Employees & EthCode \\
\hline $\begin{array}{l}\text { Louis } \\
\text { Vuitton }\end{array}$ & $\begin{array}{l}1854 \\
\text { Paris }\end{array}$ & LVMH & 3 & louisvuitton.com & 2018 & DŠ, PV & 2009 \\
\hline Gucci & $\begin{array}{c}1921 \\
\text { Florence }\end{array}$ & Kering & 9 & gucci.com & 2018 & MR, LH & 1996 \\
\hline $\begin{array}{l}\text { Dolce \& } \\
\text { Gabbana }\end{array}$ & $\begin{array}{c}1985 \\
\text { Milano }\end{array}$ & - & 28 & dolcegabbana.it & 2018 & MM & online \\
\hline Prada & $\begin{array}{c}1913 \\
\text { Milano }\end{array}$ & - & 16 & Prada.com & 2018 & MK, ER & 2007 \\
\hline $\begin{array}{l}\text { Christian } \\
\text { Dior }\end{array}$ & $\begin{array}{l}1946 \\
\text { Paris }\end{array}$ & LVMH & 4 & Christiandior.com & 2018 & EF, LŘ & 2009 \\
\hline Fendi & $\begin{array}{l}1925 \\
\text { Rome }\end{array}$ & LVMH & 12 & Fendi.com & 2018 & DF & 2009 \\
\hline Furla & $\begin{array}{c}1927 \\
\text { Bologna }\end{array}$ & - & 8 & Furla.com & 2018 & MF & - \\
\hline Tod's & $\begin{array}{c}1920 \\
\text { St.Elpidio } \\
\text { at Mare }\end{array}$ & - & 13 & Lbm.cz & 2018 & MA & $\begin{array}{c}\text { Large } \\
\text { CSR rep }\end{array}$ \\
\hline Bulgari & $\begin{array}{c}1884 \\
\text { Epirus }\end{array}$ & LVMH & 13 & Bulgari.com & 2018 & VM & 2009 \\
\hline $\begin{array}{l}\text { Bottega } \\
\text { Veneta }\end{array}$ & $\begin{array}{c}1966 \\
\text { Vicence }\end{array}$ & Kering & 14 & Lbm.cz & 2018 & VA & 1996 \\
\hline
\end{tabular}

Source: authors

Regarding the $1^{\text {st }}$ group of ambassadors, CEOs, the prima facia extrinsic and endogenous source of information about their perception of CSR is the reports prepared and signed by these CEOs for 2018. These reports are published either via eJustice portal/BRIS or on the domain of businesses. These reports, regardless of whether included in annual reports or in special CSR reports or somewhere else need to be explored by using the qualitative, quantitative text analysis, aka content analysis (Kuckartz, 2014). The processing can be done either by automatic scanning based on keywords or by holistic manual reading based on Delphi method (Okoli \& Pawlowski, 2004). The Authors prefer much more the second mentioned, because they are convinced that CSR information in particular, as well as its 
quantity and quality, cannot be reduced to a simple assumption that the mere repetition of certain words means more of a CSR commitment. In contrast, the Delphi method, while using a team of experts going over all documents, reading them, scoring them and comparing their assessment is not only far more academically robust but in addition offers further information and a deeper understanding, or at least clearer insights. The quantitative aspect was addressed by calculating the total number of pages, i.e., how many pages long was the entire annual report, on how many pages was the CSR information contained and on how much for each of its six categories. The quantitative criterion of pages rather than sentences was selected due to the linguistic, especially stylistic and pragmatic semiotic, particularities of the language. The qualitative aspect was addressed by the holistically manual approach employing a simplified Delphi method. Namely, each and every one of these reports was carefully read through by three experts on corporate matters including reporting (EC, LM and ZF, i.e., none of these three experts was one of the Authors of this paper) while following a universal set of guidelines and simple questionnaires prepared by the Authors (MacGregor Pelikánová, 2019a). All three experts master, both Czech and English, have college degrees, experience with annual reporting, at least 20 years of executive job experience and strong law and/or economic background. Two of them are women, and one is a man. Hence, their replies met the expertise expectations. These first-round replies were processed by the Authors and based on them. The Authors prepared a summary which was communicated to these three experts for the second round. Thereafter, they made a few changes with respect to their prior answers and sent their updated replies to the Authors. This data, generated from the second round, was used for the paper. Specifically, based on these guidelines and questionnaires, each of these three experts categorized the provided CSR information ( + ) or $(++)$ or $(+++)$. The guidelines required ranking as no more than general information $(+)$; to ranking as more developed and concrete information (++); and as robust information (+++) all statements about real and controllable actions culminating in an exemplary CSR behaviour. The results from the first round were processed by the Authors and resent to the experts who then provided adjusted results in the second round. These results were compared and, in the case of still different results (one expert giving more or less ++ than others), this then led to these three experts conferring with the Authors and together agreeing about the proper ranking. In addition, well-established CSR indexes such as CSR/ESG will be considered.

Regarding the $2^{\text {nd }}$ group of ambassadors, employees, the prima facia extrinsic and endogenous source of information about their perception of CSR is the direct and indirect field search performed by Authors and their collaborators. In December 2019, they made three visits to shops in Pařížská of all mentioned ten businesses, i.e. in total 30 visits. During their visits, they performed direct interviews with employees about women's leather handbags size A4 and CSR and in addition by mystery shopping aka mystery consumer aka secret shopper methods and techniques (Osterweil, 2012) collected business cards (indicating names, phones and domains) and further (indirect) information about CSR perception. In a neoliberal society where service is a commodity, consumer choice is hailed as civil liberty, and every social relationship is understood as a transaction between provider and customer, mystery shoppers are pivotal (Osterweil, 2012), especially in sectors inclined to be strongly shaped by influencers and social media voices.

In sum, in order to address these two objectives, holistic and interdisciplinary research of economic, legislative and academic sources as well as a case study entailing interviews and 
mystery shopping was performed. The prevailing strategy is exogenous and qualitative. The exploration of the yielded data employed Meta-Analysis, content, contextual and narrative analysis with identification and description, teleological interpretation, along with comparatists approach, analogy, induction and, to a restricted extent, even deduction. The partial fragmentation was overcome via the interaction of both objectives. The critical and comparative review of the evolution of the EU law on CSR and interpretation trends facilitate a deeper understanding of the current EU law on CSR as well as is a foundation to conduct the case study in one EU member state and to better explore it. The fragmentation and ambiguity of the EU law on CSR appears matched by the findings of the case study. The synergetic effect of interrelating information generated by addressing the $1^{\text {st }}$ objective and $2^{\text {nd }}$ objective allows discovering that the perception of the EU law on CSR is partially unsettled and dramatically differently by various CEOs of these luxury fashion businesses and there is an inconsistency between their attitudes and those of their employees facing the clientele in Prague.

\section{EU Law on CSR and reporting}

The concept of economic and political integration with the dominance of technocratic over political institutions (Lianos, 2010) combined with the intensification of the supranational approach over the intergovernmental approach have come together to form, to shape both the current EU, EU law and EU decade-long strategies. Despite the omnipresent blurred distinction between historical truth and reality (Chirita, 2014) and contradictions implied by the challenging overlap of law, business and IP (Vivant, 2016), the modern European integration (Marino \& Licata, 2009) is linked to the concept of the famous four freedoms of movement (MacGregor Pelikánová et al., 2017), and competition in the single internal market (MacGregor Pelikánová et al., 2016).

Modern European integration was launched by the Schuman Declaration and three treaties creating three European Communities in the 1950s when the priorities were to prevent any future military conflict, to integrate markets to increase competitiveness and to avoid hunger due to the insufficient agricultural production (Burley \& Mattli, 1993; MacGregor Pelikánová, 2018a). These original communities, as well as the later European Union, have been heterogeneous units with significant disparities between its Member States and particularly among their regions in many areas of the modern economy (Cvik \& MacGregor Pelikánová, 2019).

The situation of the current EU is complex. On the one hand, the EU and Europeans want to succeed in the global marketplace, and consequently, they are motivated towards utility maximization (MacGregor Pelikánová, 2017a). On the other hand, this drive has certain limits such as those set by the EU law and its primary, secondary and supplementary sources. The primary EU law sources are intergovernmental, while secondary EU law sources are supranational and, along with the case-law of the CJ EU, being a supplementary EU law source (MacGregor Pelikánová, 2018a). However, even more, interestingly, it suggests that, surprisingly, rather supranational actors from low-level politics (such as legal rulings, jurisprudence, etc.) rather than intergovernmental actors via high-level politics (such as international treaties, parliamentary business) have pressured for changes and their institutionalization (Favell \& Geddes, 2017). 


\subsection{The complex EU law}

The primary sources, the EU constitutional, aka foundation, triad, i.e. the Treaty on EU ("TEU"), Treaty on the Functioning of the EU ("TFEU") and Charter of fundamental rights ("Charter ") (Svoboda, 2011) underline the social and environmental dimensions (Polcyn et al., 2019), along with the economic dimension (MacGregor Pelikánová, 2018a). The TEU aims towards a highly competitive social market economy while promoting scientific and technological advances (Art.3), while TFEU focuses in more detail on the internal market, including provisions covering the right of establishment (Art.49 et foll.), capital and payments (Art.63 et foll.) and even taxation (Art.110 et foll.) and consumer protection (Art.169). In addition, TFEU covers economic cohesion (Art.174 et foll.) and administrative cooperation (Art.197). The Charter incorporates the freedom to conduct a business (art.16), right to property (Art.17), the consumer protection (Art.38) and right to good administration (Art.41) along with the right of access to documents (Art.42). MacGregor Pelikánová \& MacGregor, 2018a, MacGregor Pelikánová \& MacGregor, 2018b). Within this triad, provisions indicating the EU approach to CSR can be detected. For example, Art. 11 TFEU provides that "Environmental protection requirements must be integrated into the definition and implementation of the Union's policies and activities, in particular with a view to promoting sustainable development", Art. 12 TFEU provides that "Consumer protection requirements shall be taken into account in defining and implementing other Union policies and activities ", and Art. 168 TFEU provides "1. A high level of human health protection shall be ensured in the definition and implementation of all Union policies and activities. Union action, which shall complement national policies, shall be directed towards improving public health, preventing physical and mental illness and diseases, and obviating sources of danger to ... health..."

Secondary sources, such as Regulations and Directives, and supplementary sources, must be in compliance with primary sources. They cover human's concerns regarding sustainability (Hochman et al., 2015) and the need to not prevent and protect regarding destructive, selfish behaviour in the single internal market (MacGregor Pelikánová, 2018b) and even beyond (Piekarczyk, 2016). The content and especially the interpretation and application of both primary and secondary sources are heavily marked by the work of the top internal prointegration European tandem (Burley \& Mattli, 1993), the European Commission and the European Court of Justice ("CJ EU") (MacGregor Pelikánová, 2018a). Since the CJ EU has often done its reasoning more based upon the goals and spirit of the founding treaties and upon the determination to support integration rather than upon the positive wording of these provisions' primary or secondary legislation (Burley \& Mattli, 1993), the case-law of the CJ EU is labelled as a supplementary source of the EU law.

Indeed, relying on the literate approach, working with the very wording of the primary and secondary sources of the EU law (Svobodová, 2016), would be superficial and dramatically misleading. The spirit of the EU law is ephemerally reflected in the written outcome of these sources, and the CJ EU has enthusiastically accepted the challenge to interpret it in an almost revolutionary manner (MacGregor Pelikánová, 2014), as Costa Enel, Van Gend en Loos and Les Verts, along with academic and scientific presentations, demonstrate (Lenaerts \& Guittiérez-Fons, 2013). The CJ EU does, and perhaps even must, in so far as possible, interpret the law with a view towards filling any normative lacunae, either in primary or secondary EU law, whose persistence would "lead to a result contrary both to the spirit of the Treaty ... and to its system...", see C-294/83 Les Verts v. Parliament. Indeed, this was critical 
considering that an important reason for European integration was the reinforcement of economic cooperation between Germany and France (MacGregor Pelikánová et al., 2017), two countries not sharing identical visions of the state and social and other policies, in order to avoid future conflicts in Europe (MacGregor Pelikánová, 2014).

The vision and mission of the EU for next decade is typically incorporated in a strategy, such as the EU strategy for 2000 to 2010, aka Agenda 2000, aka Lisbon Agenda 2000 or strategy Europe 2020. These strategies are not per se a source of EU law; nevertheless, they are pivotal for the understanding of strategic priorities, including the concept of sustainability and CSR, of the EU and especially key EU institutions, such as of the European Commission or CJ EU. Lisbon Agenda 2000 had for its goal to make the EU "the most competitive and dynamic knowledge-based economy in the world, capable of sustainable economic growth by $2010 "$. This overly ambitious goal was set by EU political and economic elites (Balcerzak, 2015) to try to catch up with, and maybe even pass, the high rate of economic growth in the US and it totally failed. The reasons for this failure were numerous and heterogeneous. They basically touched and concerned all three pillars of sustainability; indeed, some of these reasons touched all three at the same time. For example, external factors such as the economic, financial, real estate, employment and other crises of 2007 and 2008 (Balcerzak, 2016a; Thalassinos \& Thalassinos, 2018; Tvrdoň, 2016; Tvrdoň et al., 2012) and internal factors such as insufficiencies in financial regulations and management responsibilities in corporate governance (Bavoso, 2012), especially due to the split between the centralized corporate governance, managed by executives (Cvik \& MacGregor Pelikánová, 2016) from "equity owners" - associates and shareholders (Cvik \& MacGregor Pelikánová, 2017), which negatively impacted economic, environmental and even social spheres. Sadly, certain EU representatives and member states blamed, for this failure, the newly accessing EU members (Wanilin, 2006). Such an explanation is neither fully correct nor in compliance with the EU's fundamental principles (MacGregor Pelikánová et al., 2016). The economic and monetary union, the Eurozone and even the single internal market were shaken to their core, and the situation remained deplorable even in 2010 when the European Commission decided to 'take the wheel', to introduce a myriad of measures, general and specific, mandatory and facultative (Jedrzejowska-Schiffauer et al., 2019) and ultimately to issue a new one-decade strategy.

The Com (2010) 2020 final Communication Europe 2020 - A strategy for smart, sustainable, and inclusive growth ("Strategy Europe 2020") was issued on 3 March 2010, a new strategy, $(E C, 2010)$. It is a strategy for three priorities - smart, sustainable and inclusive growth. Strategy Europe has five main targets - (i) to raise the employment rate to $75 \%$, (ii) to invest $3 \%$ of the GDP in R\&D, (iii) to reduce greenhouse gas emission by $20 \%$, (iv) to increase the share of the population with the tertiary education to $40 \%$ and $(v)$ to reduce the number of Europeans who are living at or below the poverty level by $25 \%$ (Turečková \& Nevima, 2016). These five targets translate into seven flagship initiatives of which at least five are related to the CSR - (i) Innovation Union, (ii) Digital Agenda for Europe with the high-speed Internet and the Digital single market, (iii) Resource-efficient Europe, (iv) Industrial policy for the globalization era and (v) Agenda for new skills and jobs (MacGregor Pelikánová, 2018b). The mentioned five main targets and seven flagship initiatives require significant resources and investments, of both public and private provenience. Indeed, a substantial part of the public investment in the EU for this purpose is done by public procurement, and it needs to be 
emphasized that the total amount spent via public procurement exceeds EUR 2 trillion, i.e. oscillates around 15\% of EU GDP (MacGregor Pelikánová \& Cvik, 2019).

The EU motto is "united in diversity" and the Strategy Europe 2020 backbone idea is "Europe can succeed if it acts collectively, as a Union". Since the single internal market with the famous four freedoms is a strategic priority, competition and competitiveness have always been at the very heart of the EU (MacGregor Pelikánová, 2018a), which now is strongly marked by digitalization and other mature society factors (Floridi, 2016). It needs to be pragmatically accepted, that the Strategy Europe 2020 is a product of the time when the European economy faced crises and post-crisis issues, the economic indicators were back to levels that took place in the 1990s (Çolak \& Ege, 2013), and there was the will to use the innovation and IS/IT even for the European Cohesion Policy (Billon et al., 2017). As the umbrella for the majority of these endeavours, the EU launched the Strategy Europe 2020 aka the pivotal policy instrument for 2010-2020 regarding competition, sustainability and even corporate governance in the EU (MacGregor \& MacGregor Pelikánová, 2019). Instead of the Directive and imposing from above approach, it opts for a multi-stakeholder model and engages all stakeholders in the sustainability concept (MacGregor Pelikánová, 2018a) and jobs (Turečková \& Nevima, 2016). These priorities, targets and flagship initiatives are intrarelated and arguably support the awareness and commitment with respect to the CSR (MacGregor Pelikánová, 2018b) and ephemeral philosophical-economical categories of ethics and fairness (Sroka \& Lörinczy, 2015).

The topics about competitiveness nowadays acquire economic interest. Although there is no uniform definition and understanding of this concept, competitiveness remains one of the fundamental criteria of economic performance evaluation in a wider comparison. The European Union set out competitiveness as one of its main objectives; successful application of instruments for competitiveness support is the assumption for its reaching, e.g. in the form of the strategy Europe 2020 (Staníčková \& Melecký, 2014). The strategy Europe 2020 carries an embedded complexity and determination to change the model of development in order to overcome the structural weaknesses and to improve its competitiveness and productivity and underpin a sustainable social market economy (MacGregor Pelikánová, 2017b). On the one hand, the Strategy Europe 2020 is impaired by the competence deficit, by setting goals which have very little to do with increasing competitiveness (Erixon, 2010) and by lacking a common denominator for the competition quality, i.e. its fairness (MacGregor Pelikánová, 2018a). On the other hand, the strategy Europe 2020 seems to have a legitimacy power to deal with digital aspects, technological potentials (Balcerzak, 2016b) and the sustainability and to be determined to go for it. Further, the strategy Europe 2020 attempts to address the dynamics between old and new EU member states (Balcerzak, 2015) and SMEs (Vokoun, 2017).

Pursuant to the strategy Europe 2020, the CSR is a dialogue and interaction between businesses, corporations and their stakeholders (Małecka et al., 2017), one who enjoys a full EU endorsement via policy support (Šebestová et al., 2018). Various policies magnify it, see, e.g. demands more transparency and shared information via public, corporate reporting with both financial and non-financial information aka CSR reporting (Matuszak \& Różanska, 2017). With respect to businesses and their sustainable corporate governance, and due to the competence spheres of the EU law, employed EU legislative instruments have included and include predominantly general and special Directives (MacGregor \& MacGregor Pelikánová, 2019). These demands for more CSR and more transparency on the market and 
in competition led to the issuance of two EU directives and one EU regulations expressly dealing with CSR and reporting - (i) Directive 2013/34/EU of 26 June 2013 on annual financial statements, consolidated financial statements and related reports of certain types of undertakings as amended by Directive 2014/95/EU and also Council Directive 2014/102/EU ("Directive 2013/34"), (ii) Directive (EU) 2017/1132 of 14 June 2017 relating to certain aspects of company law ("Directive 2017/1132") and (iii) Commission implementing regulation (EU) 2015/884 of 8 June 2015 establishing technical specifications and procedures required for the system of interconnection of registers established by Directive 2009 ("Regulation 2015/884") (MacGregor Pelikánová \& MacGregor, 2018a; MacGregor Pelikánová \& MacGregor, 2018b).

\subsection{The even more complex evolution of the EU law on CSR}

Since international law is oriented toward international law subjects and its enforceability is problematic, the international law instruments regarding CSR, such as the Brundtland Report 1987 and UN Resolution 2005, do not have a direct impact on the CSR reporting of EU businesses. In contrast, this is determined by the EU law and national laws, which implement the EU law and need to be in compliance with the EU. Hence the CSR reporting of businesses anywhere in the EU is predominantly determined by norms generated by the EU law. Although the evolution of these norms has been complex and has a direct impact on the current status quo, its study is generally omitted, and provisions in force are often presented in an incomplete and superficial fait accompli manner. It is key to overview the evolution of the EU on the CSR reporting, especially its milestones Directives, before the current provisions are cited, contextually discussed, juxtaposed and teleologically interpreted.

The primary EU law has always provided general principles to be projected in the light of the applicable strategy, such as Europe 2020, in instruments of the secondary EU law, namely in Regulations and Directives. Currently, two Directives set the legal framework for the CSR reporting in the EU and are to be transposed and implemented in national laws of all EU member states, including the Czech national law. These two Directives are Directive 2013/34, i.e. Directive 2013/34/EU of 26 June 2013 on annual financial statements, consolidated financial statements and related reports of certain types of undertakings as amended by Directive 2014/95/EU and Council Directive 2014/102/EU, and Directive 2017/1132, i.e. Directive (EU) $2017 / 1132$ of 14 June 2017 relating to certain aspects of company law. The legislative way to the currently applicable provisions from the Directive 2013/34 and Directive $2017 / 1132$ is built by a set of legislative instruments, i.e. Directives shown in Table 2.

Table 2 | Overview of the EU legislative evolution regarding CSR reporting.

\begin{tabular}{|c|c|}
\hline $\begin{array}{l}\text { Legislative instrument } \\
\text { (its status) }\end{array}$ & Key effect and CSR declarations \\
\hline $\begin{array}{l}\text { Directive } 78 / 660 / E E C \\
\text { (repealed) }\end{array}$ & $4^{\text {th }}$ Directive on the annual accounts of certain types of companies \\
\hline $\begin{array}{l}\text { Directive 82/891/EEC } \\
\text { (repealed) }\end{array}$ & $\begin{array}{c}6^{\text {th }} \text { Directive concerning the division of public limited liability } \\
\text { companies }\end{array}$ \\
\hline $\begin{array}{l}\text { Directive 83/349/EEC } \\
\text { (repealed) }\end{array}$ & $7^{\text {th }}$ Directive on consolidated accounts \\
\hline $\begin{array}{l}\text { Directive } 84 / 253 / E E C \\
\text { (still in force) }\end{array}$ & $\begin{array}{c}8^{\text {th }} \text { Directive on the approval of persons responsible for carrying out } \\
\text { the statutory audits of accounting documents }\end{array}$ \\
\hline
\end{tabular}




\begin{tabular}{|c|c|}
\hline $\begin{array}{l}\text { Directive } 2006 / 43 / E C \\
\text { on statutory audits of } \\
\text { annual accounts and } \\
\text { consolidated accounts } \\
\text { (still in force) }\end{array}$ & $\begin{array}{l}\text { Amended Directives } 78 / 660 / E E C \text { and } 83 / 349 / E E C \text { - to render the } \\
\text { relationship between the statutory auditor or audit firm and the } \\
\text { audited entity more transparent, i.e. to require disclosure of the audit } \\
\text { fee and the fee paid for non-audit services in the notes to the } \\
\text {..accounts } \\
\text { Repealed Directive } 84 / 253 / E E C \text { because it lacked a comprehensive } \\
\text { set of rules to ensure an appropriate audit infrastructure }\end{array}$ \\
\hline $\begin{array}{l}\text { Directive 2009/101/EC } \\
\text { (repealed) }\end{array}$ & $\begin{array}{l}\text { Directive as regards the interconnection of central, commercial and } \\
\text { companies registers } \\
\text { Art.2 Member States shall take the measures required to ensure } \\
\text { compulsory disclosure by companies as referred to in Article } 1 \text { of at } \\
\text { least the following documents and particulars: ... f) the accounting } \\
\text { documetns for each financial year which are required to be published } \\
\text { in accordance with Council Directives } 78 / 660 / E E C, 83 / 349 / E E C \text { and } \\
91 / 467 / E E C \\
\text { Art.3.. 3. All documents and particulars which must be disclosed } \\
\text { pursuant to Aricle } 2 \text { shall be kept in file, or entered in the register ... } \\
5 . \text { Disclosure of the documents and particulars ... shall ve effected } \\
\text { by publication in teh national gazette deisgnated for that purpose by } \\
\text { the Member State... }\end{array}$ \\
\hline $\begin{array}{l}\text { Directive } 2013 / 34 / E U \\
\text { on the annual financial } \\
\text { statements, consolidated } \\
\text { financial statements and } \\
\text { related reports of certain } \\
\text { types of undertakings } \\
\text { (still in force) }\end{array}$ & $\begin{array}{c}\text { Amended Directive 2006/43/EC - added Art.28 audit reporting (its } \\
\text { content) } \\
\text { Repealed Directives 78/660/EEC and 83/349/EEC - replaced } \\
\text { Directives 78/660/EEC and 83/349/EEC. } \\
\text { Preamble (15) In such cases, the obligation laid down in this } \\
\text { Directive to publish any accounting document in accordance with } \\
\text { Article 3(5) of Directive 2009/101/EC .. } \\
\text { Preamble (38) The annual financial statements of all undertakings to } \\
\text { which this Directive applies should be published in accordance with } \\
\text { Directive 2009/101/EC. It is, however, appropriate to provide that } \\
\text { certain derogations may be granted in this area for small and } \\
\text { medium-sized undertakings. }\end{array}$ \\
\hline $\begin{array}{l}\text { Directive 2014/95/EU } \\
\text { as regards disclosure of } \\
\text { non-financial and } \\
\text { diversity information by } \\
\text { certain large } \\
\text { undertakings } \\
\text { (still in force) }\end{array}$ & $\begin{array}{c}\text { Amended Directive 2013/34/EU - added Art.19a non-financial } \\
\text { statements, Art.29a consolidatedd non-financial statements... } \\
\text { Preamble (14) The scope of those non-financial disclosure } \\
\text { requirements should be defined by reference to the average number } \\
\text { of employees, balance sheet total and net turnover. SMEs should be } \\
\text { exempted from additional requirements, and the obligation to } \\
\text { disclose a non-financial statement should apply only to those large } \\
\text { undertakings which are public-interest entities .... having an average } \\
\text { number of employees in excess of 500... } \\
\text { Art.2 Guidance on reporting The Commission shall prepare non- } \\
\text { binding guidelines on methodology for reporting non-financial } \\
\text { information, .. }\end{array}$ \\
\hline $\begin{array}{l}\text { Directive } 2014 / 102 / \mathrm{EU} \\
\text { (still in force) }\end{array}$ & $\begin{array}{l}\text { Amended Directive 2013/34/EU - Accession of the Croation to EU } \\
\text { and thus additions to the Annex I and Annex II of the Directive } \\
2013 / 34 / E U\end{array}$ \\
\hline $\begin{array}{l}\text { Directive (EU) } 2017 / 1132 \\
\text { relating to certain } \\
\text { aspects of company law } \\
\text { (still in force) }\end{array}$ & 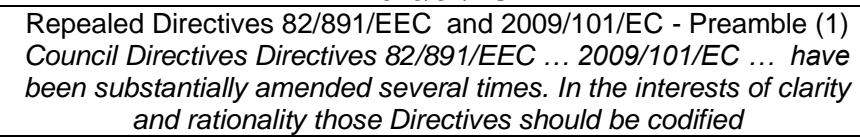 \\
\hline
\end{tabular}

Source: authors

The overview provided by Table 2 shows the Byzantine complexity suggesting that the CSR reporting in the EU is now determined by the updated, aka consolidated, version of the Directive 2013/34 and 2017/1132. This points to a tempting simplification suggesting that a literary approach to these Directives and plain readings of their provisions leads to the 
identification, description and understanding of the CSR reporting in the EU. However, the citation and study of them paint a dramatically different picture.

\subsection{The most complex current EU law on CSR and reporting}

Studies on CSR and CSR reporting in the EU generally skip the indicated legislative evolution and move to Directive 2013/34, as updated in 2014, to state that large public-interest entities with more than 500 employees must include in the management report a non-financial statement linked to the CSR and/or cite Art.19 and Art.19a (Strouhal, 2015). However, it is instrumental in analyzing Art.19 and Art.19a in the context of the entire Directive 2013/34 to see who and what (Table 2), to move to the Directive 2017/1132 to see how (Table 3 ) and to recognize that a plain reading brings more questions than answers about the CSR reporting in the EU.

Table 3 | Selected key provisions CSR reporting - Directive 2013 (consolidated version)

\begin{tabular}{|c|c|}
\hline Provision & Wording \\
\hline $\begin{array}{l}\text { Art. } 1 \\
\text { Scope }\end{array}$ & $\begin{array}{l}\text { 1. The coordination measures prescribed by this Directive shall apply to } \\
\text { the laws, regulations and administrative provisions of the Member States } \\
\text { relating to the types of undertakings listed: (a) in Annex I; ... }\end{array}$ \\
\hline $\begin{array}{l}\text { Art. } 2 \\
\text { Definitions }\end{array}$ & 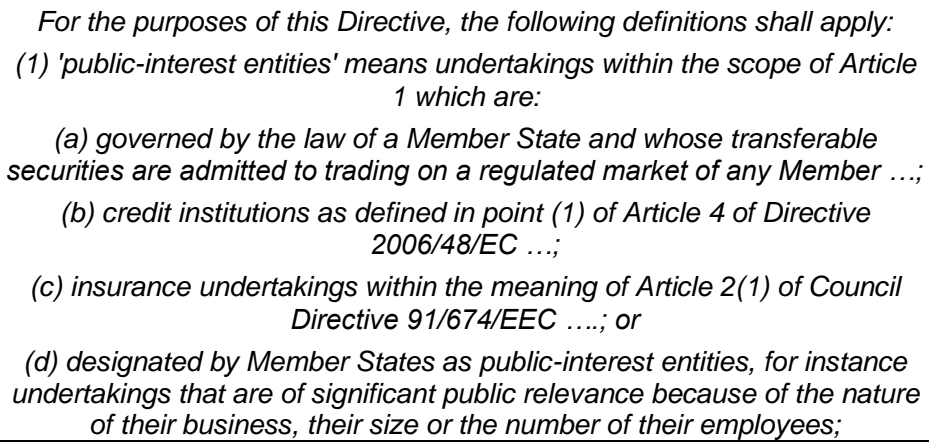 \\
\hline $\begin{array}{l}\text { Art.19 } \\
\text { Management Report }\end{array}$ & $\begin{array}{l}\text { 1. The management report shall include a fair review of the development } \\
\text { and performance of the undertaking's business and of its position, together } \\
\text { with a description of the principal risks and uncertainties that it faces. }\end{array}$ \\
\hline $\begin{array}{l}\text { Art.19a Non-financial } \\
\text { statement }\end{array}$ & $\begin{array}{l}\text { 1. Large undertakings which are public-interest entities exceeding on their } \\
\text { balance sheet dates the criterion of the average number of } 500 \text { employees } \\
\text { during the financial year shall include in the management report a non- } \\
\text { financial statement containing information to the extent necessary for an } \\
\text { understanding of the undertaking's development, performance, position } \\
\text { and impact of its activity, relating to, as a minimum, environmental, social } \\
\text { and employee matters, respect for human rights, anti-corruption and } \\
\text { bribery matters, including: } \\
\begin{array}{l}\text { (a) a brief description of the undertaking's business model; } \\
\text { (b) a description of the policies pursued by the undertaking in relation to } \\
\text { those matters, including due diligence processes implemented; } \\
\text { (c) the outcome of those policies; } \\
\text { (d) the principal risks related to those matters linked to the undertaking's...; } \\
\text { (e) non-financial key performance indicators relevant to the particular } \\
\text { business. }\end{array}\end{array}$ \\
\hline
\end{tabular}




\begin{tabular}{|l|c|}
\hline $\begin{array}{l}\text { Annex I } \\
\text { Types of undertaking }\end{array}$ & $\begin{array}{c}\text { - the Czech Republic: společnost s ručením omezeným, akciová } \\
\text { společnost; }\end{array}$ \\
- Germany: die Aktiengesellschaft, die Kommanditgesellschaft auf Aktien, \\
die Gesellschaft mit beschränkter Haftung;
\end{tabular}

Source: authors

Table 3 reveals that Directive 2013/34 uses different terminology and is ambiguous or vague. Hence, both the identification of the subject of the CSR reporting duty and the very extent of this duty is challenging. Namely, Directive 2013 deals with undertakings (Art.1), which are private limited companies, aka limited liability companies, and public limited companies, aka shareholder companies (Annex I), but imposes the duty to include non-financial statements in the management report upon large undertakings which are public-interest entities on their balance sheet dates as the criterion of the average number of 500 employees (Art.19a). This leads to the burning question about who public-interest entities are, which is only partially answered by the indication that these are entities with transferable securities, credit institutions, insurance undertakings and undertakings designated by the Member States as public-interest entities, for instance, undertakings that are of a significant public relevance because of the nature of their business, their size or the number of their employees (Art.2). This implies unanswered questions about how this designation occurs, what the criteria are and, ultimately, who are these undertakings designated by the Member States as publicinterest entities. Similarly, citation of Art.19a in Table 2 demonstrates that the content of the non-financial statements to be included in the management report CSR is described vaguely, and only the minimum threshold is indicated, i.e. environmental, social and employee matters, respect for human rights, anti-corruption and bribery matter (Art.19a). Perhaps the most puzzling identification demands, (e) non-financial key performance indicators relevant to the particular business. It is unclear, both, which businesses with more than 500 employees have to include a non-financial statement in their management report, and what exact information this non-financial statement has to include. Even worse, Directive 2017/1134 generates further confusion about the publication of this information, see Table 4. 
Table 4 | Selected key provisions of CSR reporting - Directive 2017 (consolidated version)

\begin{tabular}{|c|c|}
\hline Provision & Wording \\
\hline $\begin{array}{l}\text { Art.13 } \\
\text { Scope }\end{array}$ & $\begin{array}{c}\text { The coordination measures prescribed by this Section shall apply to the } \\
\text { laws, .... relating to the types of company listed in Annex II. }\end{array}$ \\
\hline $\begin{array}{l}\text { Art.14 } \\
\text { Documents to be } \\
\text { disclosed }\end{array}$ & $\begin{array}{l}000 \text { Member States shall take the measures required to ensure compulsory } \\
\text { disclosure by companies of at least the following documents and particulars: } \\
\text { (a) the instrument of constitution, and the statutes if they are contained in a } \\
\text { separate instrument; .... } \\
\text { (f) the accounting documents for each financial year which are required to } \\
\text { be published in accordance with Council Directives } 86 / 635 / E E C \text { (1) and } \\
91 / 674 / E E C \text { (2) and Directive } 2013 / 34 / E U \text { of the European Parliament and } \\
\text { of the Council (3); ... }\end{array}$ \\
\hline $\begin{array}{l}\text { Art.16 } \\
\text { Disclosure in the } \\
\text { register }\end{array}$ & $\begin{array}{c}\text { 1.In each Member State, a file shall be opened in a central, commercial or } \\
\text { companies register ('the register'), for each of the companies registered } \\
\text { therein...3.All documents and particulars which are required to be } \\
\text { disclosed pursuant to Article } 14 \text { shall be kept in the file, or entered in the } \\
\text { register; the subject matter of the entries in the register shall in every case } \\
\text { appear in the file. }\end{array}$ \\
\hline $\begin{array}{l}\text { Art.18 Availability of } \\
\text { electronic copies of } \\
\text { documents }\end{array}$ & $\begin{array}{c}\text { 1.Electronic copies of the documents and particulars referred to in Article } \\
14 \text { shall also be made publicly available through the system of } \\
\text { interconnection of registers. 2.Member States shall ensure that the } \\
\text { documents and particulars referred to in Article } 14 \text { are available through } \\
\text { the system of interconnection of registers in a standard message format } \\
\text { and accessible by electronic means... }\end{array}$ \\
\hline $\begin{array}{l}\text { Annex II Types of } \\
\text { companies .. in Art. } \\
13\end{array}$ & $\begin{array}{c}\text { - Czech Republic: společnost s ručením omezeným, akciová společnost; } \\
\text { - Denmark: aktieselskab, kommanditaktieselskab, anpartsselskab; } \\
\text { - Germany: die Aktiengesellschaft, die Kommanditgesellschaft auf Aktien, } \\
\text { die Gesellschaft mit beschränkter Haftung; }\end{array}$ \\
\hline
\end{tabular}

Source: authors

Table 4 reveals that Directive 2017/1134 deals only with companies (Art.13), as a matter of fact only with certain companies - namely private limited companies, aka limited liability companies, and public limited companies, aka shareholder companies (Annex II), regardless of their size, turnover or number of employees. For the interpretation and application purposes, this is good news as it allows a clear conclusion that public-interest entities with over 500 employees from Directive 2013 fit in, i.e. they must disclose the accounting documents for each financial year which are required to be published in accordance with ...Directives 86/635/EEC and 91/674/EEC and ..2013/34/EU (Art.14), submit them to be kept in the file by the central register (Art.16) in electronic copies (Art.18) and basically to be available to the public-at-large. Here comes the bad news, i.e. the burning question in re what are these accounting documents and specifically do they include non-financial statements included in the management reports by the operation of Directive 2013?

Directive 86/635/EEC on the annual accounts and consolidated accounts of banks and other financial institutions deals with the layout of their balance sheets (Art.4), and Directive 91/674/EEC on the annual accounts and consolidated accounts of insurance undertakings deals with general provisions concerning the balance sheet and the profit and loss account (Art.5). Consequently, these two Directives cover coordination measures for financial and insurance undertakings as setting three decades ago and hence are partially obsolete. Directive 2013 tells as little in this respect, see above. However, a definition of accounting documents is included in Directive 2009/101/EC, but, as already mentioned, this Directive was replaced by Directive 2017/1134, i.e. we are turning in a circle without reaching a clear definition. The only clarity emerged in 2017 when the European Commission, based on the 
power conferred by Art.2 of the Directive 2014/95/EU, issued Guidance on reporting, i.e. Communication from the Commission 2017/C 21501 Guidelines on non-financial reporting (methodology for reporting non-financial information). However, it must be emphasized that these Guidelines are not binding (Art.1) and focus only on the content (what), but not on the improvement of the identification of the subjects of the duty (who) or on the manner of the publication (how). Well, then, in all these complexities, the only thing clear and obvious is the Regulation 2015/884 with its instruction to use eJustice portal and BRIS system to migrate the data from all EU member state's national business registers about businesses (MacGregor Pelikánová \& MacGregor, 2017).

\section{Case Study - Perception of CSR by Pařižžsá ambassadors}

Often the setting of the law and appropriate regimes is one thing, and their application is something dramatically different. A proper and committed perception of the EU approach to the CSR is a pre-requirement for the EU expected approach to CSR by a critical group of stakeholders shaping the CSR of the entire business - the ambassadors of luxury fashion businesses. These ambassadors are either de iure representatives of these businesses, CEOs preparing, issuing and signing reports, or either de facto representatives of these businesses, i.e. employees facing the clientele in the „5th Avenue“, i.e. Pařižská street in Prague for the Czech Republic.

\subsection{CEOs perspective - reports of luxury fashion businesses}

For 2018, all ten included luxury fashion businesses issued, via CEOs, and made freely electronically available, reports including CSR information. These reports were automatically scanned for keywords and manually explored via the Delphi method while paying particular attention to six CSR categories. Table 5, below, summarizes the data extracted from these reports. 
Table 5 | CEO's perception based on CSR reports - frequency of key worquality of information

\begin{tabular}{|l|c|c|c|c|c|c|}
\hline & Environment & Employee & Social & $\begin{array}{c}\text { Human } \\
\text { Right }\end{array}$ & $\begin{array}{c}\text { Anti- } \\
\text { Corruption }\end{array}$ & R\&D \\
\hline $\begin{array}{l}\text { Louis } \\
\text { Vuitton }\end{array}$ & $20 /+$ & $143 /+++$ & $70 /++$ & $54 /++$ & $1 /++$ & $6 /+$ \\
\hline Gucci & $44 /+++$ & $67 /+$ & $25 /+$ & $11 /+++$ & $0 / 0 .$. & $4 /+$ \\
\hline $\begin{array}{l}\text { Dolce Gabbana } \\
\text { \& }\end{array}$ & + & + & + & + & + & + \\
\hline Prada & $15 /+++$ & $43 /++$ & $11 /++$ & $0 /$ & $0 /$ & $9 /+++$ \\
\hline $\begin{array}{l}\text { Christian } \\
\text { Dior }\end{array}$ & $20 /+$ & $143 /+++$ & $70 /++$ & $54 /++$ & $1 /++$ & $6 /+$ \\
\hline Fendi & $20 /+$ & $143 /+++$ & $70 /++$ & $54 /++$ & $1 /++$ & $6 /+$ \\
\hline Furla & 0 & 0 & + & 0 & 0 & + \\
\hline Tod's & $66 /+++$ & $178 /++$ & $51 /+++$ & $7 /+++$ & $23 /++$ & $15 /++$ \\
\hline Bulgari & $20 /+$ & $143 /+++$ & $70 /++$ & $54 /++$ & $1 /++$ & $6 /+$ \\
\hline $\begin{array}{l}\text { Bottega } \\
\text { Veneta }\end{array}$ & $44 /+++$ & $67 /+$ & $25 /+$ & $11 /+++$ & $0 / 0 .$. & $4 /+$ \\
\hline
\end{tabular}

Source: authors based on CSR reports signed by CEOs and available via eJustice or from the business's domains.

The LVHM group, i.e. Louis Vuitton, Christian Dior, Fendi and Bulgari, has prepared a separate and freely electronically available „LVMH 2018 Social Responsibility Report“ with 54 and signed by Chantal Gaemperle Director of Human Resources and Synergie, which was preceded by „LVMH 2017 Social Responsibility Report“ with 97 pages. The most heavily used keyword in "LVMH 2018 Social Responsibility Report“ was „employee“ with 143 appearances. Regarding the environment protection, general proclamations are made. Concerning employee matters, LVMH is a pro-women, pro-older and pro-disabled employer. LVMH recognizes the importance of social matters and community concerns by supporting education and young creators, by encouraging starts-up and by co-operating with UNICEF and the "Save Children" program. Respect for human rights is cemented by the direct reference to UDHR and other UN and OECD documents. Even anti-corruption and bribery matters and R\&D are mentioned. The "LVMH 2018 Social Responsibility Report" focusses on partnerships and addresses specifically the UN Agenda 2030 with 17 SDGs. LVMH adopted its Code of Conduct in 2009 and revised it in 2017.

The Kering group, i.e. Gucci and Bottega Veneta, has prepared a „2018 Integrated Report“ which was signed by François-Henri Pinault, Chairman and CEO, and is freely electronically available. The „2018 Integrated Report“ has 38 pages, and the most heavily used word is again „employee" with 67 appearances. Environmental protection seems absolutely pivotal, and the Kering group commits to reduce $\mathrm{CO} 2$ emissions by $50 \%$ (Science-Based Target), to ensure $100 \%$ traceability in the Group's key raw materials and to achieve the highest standards in animal welfare. General statements are provided regarding employee matters and social matters, community concerns and R\&D, while a clear commitment even for suppliers is expressed with respect to human rights (origin of gold or diamonds). Anticorruption and bribery matters are not mentioned. In 2018, Kering published the Kering Standards, an official list of advanced industry environmental and social requirements for its 
brands and suppliers. "Our ambition is to redefine luxury to help influence and drive these positive changes," says Marie-Claire Daveu, Kering's chief sustainability officer (Deloitte, 2019). In 1996, the first Kering group Ethics charter was issued and in 2018 was significantly expanded.

Dolce \& Gabbana has posted on their Domain a "Code of Ethics“, but not its reports. Indeed, neither financial statements nor non-financial statements are freely electronically available. The Code of Ethics is approximately ten pages long and deals with all CSR categories specifically, but not in deep detail. Considering the nature of the concept and myriad of issues (racism, sexism and homophobia) and legal cases (tax evasion), it is quite understandable that CSR is important, but not at the centre of importance for Dolce \& Gabbana.

Prada has prepared an „Annual Report 2018“ which was signed by Miuccia Prada and Patrizio Bertelli, CEOs, and is freely electronically available. The „Annual Report 2018“ has 244 pages and the most heavily used word is "employee“ with 43 appearances. The most highly detailed category covered in environmental protection with the Prada drive for $100 \%$ renewable resources (energy) and its commitment to originality and independence. Indeed, the design and product development costs for the 2018 twelve-month period amounted to EUR 125.2 million. In contrast, there are no developed sections on employee matters; instead, there is a note about ongoing labour law disputes. Back in 2007, Prada was one of the first in this field to adopt a Code of Ethics regulating on a daily basis the Group's working life. The company is also a promoter of many sustainability activities: it supports the "Manifesto of sustainability for Italian Fashion" and is a member of the 'Sustainability, Ecology and Environment Commission' that aims at creating shared environmental and ethical standards among the main players of the Italian fashion industry. Prada has also contributed to the "Guidelines on eco-toxicological requirements for articles of clothing, leather goods, footwear and accessories" which introduces new and more stringent parameters for the use of chemicals to improve product safety and reducing pollution (Deloitte, 2019).

Furla has posted neither on its Domain any reports, nor somewhere else these reports are not freely electronically available. Nevertheless, Furla issued freely electronically available CSR statement highlighting its interest and support for culture, creativity, young artists and creators and social projects.

Tod's has prepared a „2018 Annual Report“ which was signed by Diego Della Valle, CEO, and is freely electronically available. The „2018 Annual Report“ has 277 pages, and the most heavily used word is again „employee“ with 178 appearances. The „2018 Annual Report“ has a special section (p.41-59) called „Approach to Sustainability“ with Tod's Sustainability Plan aiming to engage all stakeholders and establish a CSR partnership. Even more interestingly, there is a whole section (p.98-118) called "Ethics“ dealing with the fair treatment and wellbeing of employees and with environmental protection, such as emission and water protection. A strong emphasis is paid as well to tradition, creativity and solidarity. As a matter of fact, another section (p.119-129) is called "Solidarity and Italian Spirit" and covers a myriad of community social projects. 


\subsection{Employees perspective - Pařížská interviews and mystery shopping}

In December 2019, a repeated field search of all ten luxury fashion businesses included was performed entailing both interviews and mystery shopping. The leitmotif was to obtained information about a luxury leader bag A4 format and about CSR in general. Table 6, below, summarizes the data extracted from these shop visits, especially from their employees, i.e. how they present their business and its CSR.

Table 6 | Employees' perception based on interviews and mystery shopping

\begin{tabular}{|c|c|c|c|c|c|c|}
\hline & Environm. & Empl.Mat. & Social & HumRight & Anti-Corr. & R\&D \\
\hline Louis Vuitton & ++ & + & ++ & 0 & 0 & + \\
\hline Gucci & +++ & ++ & + & 0 & 0 & + \\
\hline $\begin{array}{ll}\text { Dolce } & \& \\
\text { Gabbana } & \end{array}$ & + & ++ & +++ & 0 & 0 & + \\
\hline Prada & +++ & ++ & + & 0 & 0 & ++ \\
\hline $\begin{array}{l}\text { Christian } \\
\text { Dior }\end{array}$ & ++ & + & ++ & 0 & 0 & ++ \\
\hline Fendi & ++ & + & ++ & 0 & 0 & ++ \\
\hline Furla & + & ++ & + & + & 0 & + \\
\hline Tod's & ++ & ++ & + & 0 & 0 & + \\
\hline Bulgari & ++ & ++ & ++ & 0 & 0 & ++ \\
\hline $\begin{array}{l}\text { Bottega } \\
\text { Veneta }\end{array}$ & +++ & ++ & + & 0 & 0 & + \\
\hline
\end{tabular}

Source: authors

Manifestly, the ambassador's perspectives differ dramatically and not only across businesses but even within the same business, i.e. Table 5 and Table 6 indicate that not only are there very few similarities between the CSR perception by businesses, but even that the ambassadors of the same business, CEO v. employees facing the clientele, do not share the same CSR perception. As a matter of fact, the only common denominator is rather sad employees have rather low awareness about their business CSR commitment.

\section{Results and Discussion}

For over five decades, various European Directives have been issued in order to harmonize the accounting practices of European businesses. During the last decade, this trend focusing on financial statements has been expanded to non-financial statements, aka CSR statements, including its public disclosure via online registers, and Directive 2013/34 and Directive 2017/1134 are perceived as clear and conclusive sources for this legal backbone. Nevertheless, the evolution of the EU was complicated and impacted these Directives. A study of pertinent provisions of these two Directives reveals their inconsistency and not their inter-relation, i.e. they develop independently without considering each other and without using the same approach or terminology. Although the CSR means very little if not made 
transparent and public, it remains unclear who exactly is the subject of the duty to do CSR reporting, due to the hesitant harmonization drive of Directive 2013/34. Interestingly, Directive $2017 / 1134$ demonstrates a much better determination and easily moves to clearly identify who has to file such information and documents, i.e. basically all limited companies. Not only the subjects of the duty, but even the content of this duty remains hidden in obscurity. The novelization in 2014 of Directive 2013/34 attempted to address it by delegating the power to the Commission, which used it in 2017 to issue non-binding guidelines. Hence, there are some hints but not final law instructions. To complete this threesome of uncertainty, the doubts about the who and what are complemented by hesitations about how. Namely, Directive $2017 / 1134$ provides some indices about the publication and available access but is silent about the details and realization. Well, what is the strategic and legislative will of the EU regarding CSR reporting? Does the EU want to regulate it or at least harmonize it and, if yes, should we go at least for a full harmonization or should EU member states have a free hand? Or does the CSR reporting belong to the sphere of the soft law? The evolution and current status quo of the EU law on CSR reporting suggest that, despite the best intentions, the EU lacks the vision and/or courage to go full steam ahead for it. This is deplorable and needs to be resolved because, without any clear understanding of the legal framework for the CSR reporting, hardly any CSR reporting studies in the EU could be properly appreciated.

The case study regarding luxury fashion businesses, namely the perception of CSR by their ambassadors, demonstrates an even larger fragmentation and confusion with one single common denominator - a low awareness of bottom stakeholders regarding preferences of upper stakeholders. These businesses differ in their CSR commitment, and this even if they belong in the same group. Interestingly, perhaps the only common point for all ambassadors of these luxury fashion businesses is the moderate interest in social and community matters, and exactly the same finding was proposed regarding more heterogeneous groups of Czech businesses (Kašparová, 2018).

The top management of the LVHM group, i.e. Louis Vuitton, Christian Dior, Fendi and Bulgari, has prepared an impressive „LVMH 2018 Social Responsibility Report“ dealing very well with all six CSR categories and, based on quantitative as well as qualitative measures, ranked as the strongest „employee matters“. However, the field search, especially by Louis Vuitton and Christian Dior, showed dramatic deficiencies in this sphere - there is a massive fluctuation of employees and, despite their proclamation, their training is behind expectations leading to ignorance (Louis Vuitton) and even arrogancy (Christian Dior). The situation by Fendi and Bulgari was much better in this respect. Nevertheless, there were neither indices nor whatever knowledge about Human Rights or Anti-Corruption aspects of CSR.

The top management of the Kering group, including Gucci and Bottega Veneta, has prepared a „2018 Integrated Report“. Although it mentions employees“ frequently, its focus belongs to the „environment“, namely emissions and animal welfare. Unlike LVHM, here the information managed to come across, and the employees are aware of it and endorse it (especially the animal welfare issue). The employee's proclamations about animal welfare even appeared as extreme (animals receiving names and guilt statements). However, they know nothing or very little about the remaining CSR categories.

The top management of Dolce \& Gabbana has posted on their Domain a "Code of Ethics“, but not its reports. Indeed, CSR does not seem to be at the centre of their attention, even less in the focus of their employees. At the same time, they seem to be consistent and truly 
linked to the Italian family heritage. This can be contrasted with Prada with a strong commitment to CSR, expressed both by the top management and its employees, especially regarding the environment (renewal energy and animal welfare). Similar to Gucci employees, even Prada employees seem extremely (over)concerned regarding animal welfare. In Prada, they even pushed further the idea that no natural fur should be used in the future. This is the total opposite of the Karl Lagerfeld „funny fur" concept for Fendi from LVHM group. Top management and employees Furla seem somewhat similar to those from Dolce \& Gabbana, i.e. the CSR as such is not the top priority, and the focus goes just for social projects and culture, but not soo much traditionalist as Dolce \& Gabanna (see the Furla drive to link to Euro-Asian concept). On the other side of the spectrum is the top management of Tod's, as they prepared a „2018 Annual Report“ which is perhaps even more impressive and detailoriented than the „LVHM 2018 Social Responsibility Report“. However, their employees have only a rather fragmented knowledge in this respect.

These results are even more interesting in the light of available indexing. According to the CSR HUB Sustainability Management Tools CSR/ESG ranking, the leaders are Gucci (96\%), Louis Vuitton (92\%), Christian Dior (89\%), while the CSR underperformers should be Tod's (28\%), and Fendi (22\%) (CSR Hub, 2019). This confirms the case study conclusion about the differences within the same group (Louis Vuitton v. Fendi) and about the top determination for the environment by Gucci. However, it does not confirm the position of Prada, and even this contradicts the superior CSR report of Tod's.

\section{Conclusion}

CSR is absolutely pivotal for the sustainability of our global highly-competitive society. The EU is aware of it and via a complex evolution brought a partially mandatory framework regarding the CSR and CSR reporting. The first objective of this paper was satisfied by a detailed and critical assessment of this evolution and by a teleological holistic interpretation of the current EU law in this respect. The second objective was satisfied by the performance of a totally pioneering case study about the perception of CSR by businesses from the luxury fashion industry supposed to be the leading CSR force, especially their ambassadors - CEOs and employees facing the clientele in Pařižská street in Prague.

The critical and comparative review of the evolution of the EU law on CSR shows piecemeal trends and a lack of permanent consent. This is not fatal per se and could be overcome by a pro-active and pragmatic approach. However, this fragmentation and ambiguity are further magnified by worrisome findings of the case study. The perception of the EU law on CSR is dramatically different among the various CEOs of these luxury fashion businesses, and there is an inconsistency between their attitudes and those of their employees facing the clientele in Prague. Naturally, businesses might differ in their CSR, but any inconsistency should be within the same group and absolutely not at all between the same business CEOs and employees facing the clientele. Such inconsistency undermines the effectiveness and efficiency of the CSR regime, devalues the CSR awareness and needs to be corrected.

\section{Acknowledgement}

This paper is the result of the Metropolitan University Prague research project no. 74-02 "Territorial Studies, Economics, International Relations" (2020) based on a grant from the Institutional Fund for the Long-term Strategic Development of Research Organisations. 


\section{References}

Albu, N., Albu, C. N., Dumitru, M. \& Dumitru, V. F. (2013). Plurality or convergence in sustainable reporting standards? Amfiteatru Economic - Business and Sustainable Development, 15(7): 729742.

Anand, S. \& Sen, A. (2000). Human development and economic sustainability. World Development, 28(12): 2029-2049.

Andrikopoulos, A., Samitas, A. \& Bekiaris, M. (2014). Corporate social responsibility reporting in financial institutions: Evidence from Euronext. Research in International Business and Finance, 32, 27 35.

Areeda, Ph. E. (1996). The Socratic method. Harvard Law Review, 109(5): 911-922.

Bar-Tal, D. (1986). Altruistic motivation to help: Definition, utility and operationalization. Humboldt Journal of Social Relations, 13(1/2): 3-14.

Balcerzak, A. P. (2015). Europe 2020 Strategy and Structural Diversity Between Old and New Member States. Application of Zero Unitarization Method for Dynamic Analysis in the Years 2004-2013. Economics and Sociology, 8(2), 190-210. DOI: https://doi.org/10.14254/2071-789X.2015/8-2/14

Balcerzak, A. P. (2016a). Fiscal Burden in the European Union Member States. Economic Annals - XXI, 161(9-10):4-6.

Balcerzak, A. P. (2016b). Technological Potential of European Economy. Proposition of Measurement with Application of Multiple Criteria Decision Analysis. Montenegrin Journal of Economics, 12(3): 7-17. DOI: https://doi.org/10.14254/18005845.2016/12-3/1.

Bansal, P. \& Song, H. C. (2017). Similar But Not the Same: Differentiating Corporate Sustainability from Corporate Responsibility. Academy of Management Annals, 11(1), 105-149. DOI: https://doi.org/10.5465/annals.2015.0095

Barnett, M. L. (2007). Stakeholder influence capacity and the variablity of financial return to corporate social responsibility. Academy of Management Review, 32(3): 794-816. DOI: https://doi.org/10.5465/amr.2007.25275520

Bavoso, V. (2012). Explaining Financial Scandals: Corporate Governance, Structured Finance and the Enlightened Sovereign Control Paradigm. Cambridge Scholars Publishing.

Berman, S. L., Wicks, A. C., Kotha, S. \& Jones, T. M. (1999). Does stakeholder orientation matter? The relationship between stakeholder management models and firm financial performance. The Academy of Management Journal, 42, 488-506.

Bhati, A. S. (2005). Robust Spatial Analysis of Rare Crimes: An Information-Theoretic Approach. Sociological Methodology, 35, 239-302.

Bhattacharya, C. B. \& Sen, S. (2004). Doing better at doing good: When, why, and how consumers respond to corporate social initiatives. California Management Review, 47, 9-24.

Billon, M., Marco, R., Lera-Lopez, F. (2017). Innovation and ICT use in the EU: an analysis of regional drivers. Empirical Economics, 53(3): 1083-1108. DOI: https://doi.org/10.1007/s00181-016-1153$\mathrm{x}$

Bunn, I. D. (2004). Global Advocacy for Corporate Accountability: Transatlantic Perspectives from the NGO Community. American University International Law Review, 19(6):1265-1306.

Burley, A. M. \& Mattli, W. (1993). Europe Before the Court: A Political Theory of Legal Integration. International Organization, 47(1): 41-76. 
Chandler, D. (2017). Strategic Corporate Social Responsibility: Sustainable Value Creation. Thousand Oaks, CA : SAGE Publications.

Chirita, A. D. (2014). A legal-historical review of the EU competition rules. International and comparative law quarterly, 63(2): 281-316.

Cvik, E. D. \& MacGregor Pelikánová, R. (2016). A comparative study of the legal liability of executives in LLC in the Czech Republic \& some of other EU member states, Scientific Papers of the University of Pardubice, Series D: Faculty of Economics and Administration, 23(36): 54-65.

Cvik, E. D. \& MacGregor Pelikánová, R. (2017). The Volatively Sujective Nature and Value of Stock Czech Case Study, Ad Alta - Interdisciplinary Research, 7(2): 40-45. DOI: https://doi.org/10.1007/s40319-016-0472-y

Cvik, E. D. \& MacGregor Pelikánová, R. (2019). The (Mis)compliance of objectives of new CAP Legislative, Academic and General Public Perspectives. European Countryside, 11(1): 143-161. DOI: https://doi.org/10.2478/euco-2019-0009.

Çolak, M. S. \& Ege, A. (2013). An Assessment of EU 2020 Strategy: Too Far to Reach? Social Indicators Research, ,110(2): 659-680.

Deloitte (2019). Global Powers of Luxury Goods 2019. Bridging the gap between the old and the new. Retrieved January 5, 2020, from https://www2.deloitte.com/content/dam/Deloitte/es/Documents/bienes-comsumo-distribucionhosteleria/Deloitte-ES-consumer-industry-global-powers-luxury-goods-2019.pdf

Diekhof, E. W., Wittmer, S. \& Reimers, L. (2014). Does competition really bring out the worst? Plos One, 9(7). DOI: 10.1371/journal.pone.0098977.

Dubois B. \& Paternault, C. (1995). Observations: understanding the world of international luxury brands. Journal of Advertising Research, 35(4): 69-76.

Dvouletý, O. (2017). What is the Relationship between Entrepreneurship and Unemployment in Visegrad Countries? Central European Business Review, 6(2):42-53. DOI: 10.18267/j.cebr.179

Erixon, F. (2010). The Europe 2020 strategy: time for Europe to think again. European view, 9(1):29-37. DOI: https://doi.org/10.1007/s12290-010-0120-8

European Commission. (2010). Communication from the Commission EUROPE 2020. A strategy for smart, sustainable and inclusive growth. (“Europe 2020 Strategy”). Retrieved June, 30, 2020 from https://ec.europa.eu/eu2020/pdf/COMPLET\%20EN\%20BARROSO\%20\%20\%20007\%20\%20Europe\%202020\%20-\%20EN\%20version.pdf

El Ghoul, S., Guedhami, O., Kwok, C. C. \& Mishra, D. R. (2011). Does corporate social responsibility affect the cost of capital? Journal of Banking \& Finance, 35(9): 2388-2406.

Favell, A. \& Geddes, A. (1997). European Integration, Immigration and the Nation State: Institutionalising Transnational Political Action? San Domenico: European University Institute - EUI Working Papers RSC No. 99/32, 1999, 7. Retrieved January 5, 2020, from http://www.eui.eu/RSCAS/WPTexts/99_32.pdf

Fehr, E. \& Fischbacher, U. (2016). Human altruism-proximate patterns and evolutionary origins. Analyse \& Kritik, 27(1): 6-47. DOI: https://doi.org/10.1515/auk-2005-0101

Floridi, L. (2016). Mature information societies - a matter of expectations, Philosophy and Technology, 29, 1-4. DOI: https://doi.org/10.1007/s13347-016-0214-6.

Friedman, M. (2007). The Social Responsibility of business is to Increase its Profits. In: Zimmerli W.C., Holzinger M., Richter K. (eds) Corporate Ethics and Corporate Governance. Springer, Berlin, Heidelberg, 173-178. DOI: https://doi.org/10.1007 
Galbreath, J. (2013). ESG in focus: The Australian evidence. Journal of Business Ethics, 118(3): 529541. DOI: https://doi.org/10.1007/s10551-012-1607-9.

Gallardo-Vázquez, D., Valdez, L. \& Castuera-Diáz, A.M. (2019). Corporate Social Responsibility as an Antecedent of innovation, Reputation, and Competitiveness Success: A Multiple Mediation Analysis. Sustainability, 11(20): 5614. DOI: https://doi.org/10.3390/su11205614.

Gillai, B., Rammohan, S. V. \& Lee, H. L. (2014). Managing Supply Chain Sustainability and Intellectual Property: Are They More Similar than Different? Stanford Initiative for the Study of Supply Chain Responsibility, March 2014.

Glass, G. V. (1976). Primary, secondary, and meta-analysis of research. Educational Researcher, 5 (10): $3-8$.

Goss, A. \& Roberts, G. (2011). The Impact of Corporate Social Responsibility on the Cost of Bak Loans. Journal of Banking and Finance, 35(7): 1794-1810.

Han, Y. J., Nunes, J. C. \& Dreze, X. (2010). Signaling Status with Luxury Goods: The Role of Brand Prominence. Journal of Marketing, 74(4): 15-30.

Haski-Leventhal, D. (2018). Strategic Corporate Social Responsibility. Los Angeles : SAGE Publication.

Heckman, J. J.(2005a). The Scientific Model of Causality. Sociological Methodology, 35, 1-98.

Heckamn, J. J. (2005b). Rejoinder: Response to Sobel. Sociological Methodology, 35, 135-162.

Hochman, G., Shahar, A. \& Ariely, D. (2015). Fairness requires deliberation. The primacy of economic over social considerations. Frontiers in Psychology, 6. DOI: https://doi.org/10.3389/fpsyg.2015.00747.

Ikram, A., Li, Z.F. \& Minor, D. (2019). CSR-contingent executive compensation contracts. Journal of Banking \& Finance. DOI: 10.1016/j.jbankfin.2019.105655.

Jedrzejowska-Schiffauer, I., Schiffauer, P. \& Thalassinos, E. (2019). EU Regulatory Measures Following the Crises: What Impact on Corporate Governance of Financial Institutions? European Research Studies Journal, 22(3), 432-456. DOI: https://doi.org/10.35808/ersj/1488.

Jindřichovská, I. \& Purcarea, I. (2011). CSR and Environmental Reporting in the Czech Republic and Romania: Country Comparison of Rules and Practices. Accounting and Management Information Systems, 10(2), 202-227.

Kale, G. Ö. \& Öztürk, G. (2016). The importance of sustainability in luxury brand management. Intermedia International e-Journal, 3(4): 106-126.

Kašparová, K. (2018). The Czech CSR Reports: Topics and Quality of Their Processing. Acta academica karviniensis, XVIII(2): 5-15.

Knapp, V. (1995). Teorie práva. [Theory of Law] $1^{\text {st }}$ edition. Prague, CZ : C. H. Beck.

Knapp, V. (2003). Vědecká propedeutika pro právníky [Scientific Propedeutics for Lawyers]. Bratislava, SR : Eurolex Bohemia.

Knapp, V. \& Gerloch, A. (2012). Právní propedeutika [Legal Propedeutics]. 2 ${ }^{\text {nd }}$ Edition. Plzeň, CZ : Vydavatelství a nakladatelství Aleš Čeněk.

Konrath, S. H. (2011). Changes in dispositional empathy in American college students over time: A metaanalysis. Personality and Social Psychology Review, 15(2): 180-198. DOI: $10.1177 / 1088868310377395$ 
Krause, J. (2015). The Potential of Environmentally Friendly Business Strategy - Research from the Czech Republic. International Journal of Engineering Business Management, 7(6): 1-6. DOI: $10.5772 / 60064$

Křečková Kroupová, Z. (2015). The Latest Trends in the Corporate Sustainability and its Implications for Czech Businesses. Central European Business Review, 4(2):12-20.

Kuckartz, U. (2014). Qualitative Text Analysis - A Guide to Methods, Practice and Using Software. $1^{\text {st }}$ Edition. Sage Publications Ltd.

Lenaerts, K. \& Guttiérez-Fons, J.A. (2013). To Say What the Law of the EU Is? Methods of Interpretation and the European Court of Justice. Academy of European Law, 9, 1-55.

Li, F., Minor, D., Wang, J. \& Yu, C. (2019). A learning curve of the market. Chasing alpha of socially responsible firms. Journal of Economic Dynamics and Control, 109, 103772.

Lianos, I. (2010). Shifting Narratives in the European Internal Market: Efficient Restrictions of Trade and the Nature of “Economic" Integration'. European Business Law Review, 21(5): 705-760.

MacGregor, R. K. \& MacGregor Pelikánová, R. (2019). Shareholder Engagement for Corporate Governance in the Light of the Harmonization and Transposition. International Journal of Economics and Business Administration, VII(4): 22-34.

MacGregor Pelikánová, R. (2014). Selected current aspects and issues of European integration. Ostrava, CZ: Key Publishing.

MacGregor Pelikánová, R. (2017a). European Myriad of Approaches to Parasitic Commercial Practices. Oeconomia Copernicana, 8(2), 167-180. DOI: https://doi.org/10.24136/oc.v8i2.11.

MacGregor Pelikánová, R. (2017b). Supranational Europe 2020 Competitiveness - Questionable Effectiveness, Efficiency and Value Compliance. In Nálepková, V., Št’astná, J. Conference Proceedings - International Scientific Conference - Economic policy in the Global Environment. Havírov: Vysoká škola sociálně správní.

MacGregor Pelikánová, R. (2017c). Constantine's Christianity for the (Dis)integrated EU - Déjà vu of Constantine's Roman governance reflecting of the mistrial of Jesus for EU? Dialogo, 4(1): 81 98.

MacGregor Pelikánová, R. (2018a). European drive for fair competition - nature and impact of the harmonized protection against unfair commerical practices. Ostrava: Key Publishing and Praha: MUP Press.

MacGregor Pelikánová, R. (2018b). The nebulous effectiveness, efficiency and fairness of the European e-Justice Portal vis-à-vis Corporate Social Responsibility. Progress in Economic Sciences, 5, 127-141. DOI: https://doi.org/10.14595/PES/05/008.

MacGregor Pelikánová, R. (2018c). Fostering Innovation - a Myth or Reality of the EU in 2018 In: Staníčková, M., Melecký, L., Kovářová, E., Dvoroková, K. (Eds.). Proceedings of the ${ }^{4 \text { th }}$ International Conference on European Integration 2018, May 17-18, 2018, Ostrava, 965-973 of 1121.

MacGregor Pelikánová, R. (2019a). Corporate Social Responsibility Information in Annual Reports in the EU - Czech Case Study. Sustainability, 11, 237. DOI:10.3390/su11010237.

MacGregor Pelikánová, R. (2019b). Harmonization of the protection against misleading commercial practices: ongoing divergences in Central European countries. Oeconomia Copernicana, 10(2), 239-252. DOI: https://doi.org/10.24136/oc.2019.012.

MacGregor Pelikánová, R. (2019c) R\&D expenditure and innovation in the EU and selected member states. JEMI, 15(1):13-33. DOI: https://doi.org/doi.org/10.7341/20191511. 
MacGregor Pelikánová, R. (2019d). The Fair Analysis of the Case law of the Court of Justice of EU on the Unfair Commercial Practices. Acta Academica Karviniensia, (1): 47-58.

MacGregor Pelikánová, R (2019e). Corporate Social Responsibility for Fair Commercial Practices and Intellectual Property: Real Potential? Toruń, PL : Institute of Economic Research and Polish Economic Society Branch. DOI: https://doi.org/10.24136/eep.mon.2019.1.

MacGregor Pelikánová, R. \& Beneš, M. (2017). Does the Full Harmonization of the Consumers'Protection Against Unfair Commercial Practices Via UCPD Fit in Europe 2020? Czech Yearbook of International Law - CYIL, 8, 223-231.

MacGregor Pelikánová, R., Beneš, M. \& MacGregor, R. (2016). European (mis)reconciliation of rules against misleading Commercial practices - the Last decade's crusade of the Commission and CJ EU. In Majerová, I., Kotlánová, E. (eds.). Proceedings of the 14th International Conference „Economic policy in the European Union Member Countries“, 389-398 of 424.

MacGregor Pelikánová, R., Císařová, J. \& Beneš, M. (2017). The misleading perception of the purpose of the protection against misleading advertising by the EU law and its impact in the Czech Republic. The Lawyer Quarterly, 7(3): 145-161.

MacGregor Pelikánová, R. \& Cvik, E.D. (2019). Awareness and Perception of Modernized Electronic Public Procurement - Czech Case Study. Ad Alta - Journal of Interdisciplinary Research, 9(1): 34-40.

MacGregor Pelikánová, R. \& MacGregor, R. (2017). European e-Justice Portal - Reality of Electronic One-Stop-Shop for Publication of Financial Statements in the EU. In: Jindřichovská, Irena; Kubičková, Dana. Conference: 5th International Scientific Conference on IFRS - Global Rules and Local Use. Anglo-American University.

MacGregor Pelikánová, R. \& MacGregor, R. (2018a). Corporate Social Responsibility e-Reporting as a tool for (Un)fair competition in the EU. In Löster, T.; Pavelka, T. (Eds.). Conference Proceedings. The $12^{\text {th }}$ International Days of Statistics and Economics. University of Economics, Prague.

MacGregor Pelikánová, R. \& MacGregor, R. (2018b). Reality of e-Reporting of Annual Accooutns of SMEs in the EU - McDonald's, BurgerKing, KFC and Subway Case Study. In: Jindrichovská, I.; Kubičková, D. $6^{\text {th }}$ International Scientific Conference on IFRS - Global Rules and Local Use Location: Anglo-American University, Prague.

MacGregor Pelikánová, R. \& MacGregor, R. (2019). The Impact of the New EU Trademark Regime on Entrepreneurial Competitiveness. Forum Scientiae Oeconomia, 7(2): 59-70. DOI:10.23762/FSO_VOL7_NO2_4.

Mallin, Ch. (2018). Corporate Governance. $6^{\text {th }}$ Edition. Oxford, UK: Oxford University Press.

Małecka, J., Łucka, T., Šebestová, J. \& Šperka, R. (2017) Economic Activity and Social Determinants Versus Entrepreneurship in SMEs - Selected Aspects. Copernican Journal of Finance \& Accounting, 6(3): 47-61. DOI: https://doi.org/10.12775/CJFA.2017.016.

Marino, I. \& Licata, G.F. (2009). The Law of Integration: An Introduction. Transylvanian Review of Administrative Sciences, $28 \mathrm{E} \mathrm{SI} / 2009,236-248$.

Marinova, D. \& Raven, M. (2006). Indigenous Knowledge and Intellectual Property: A Sustainable Agenda. Journal of Economic Surveys, 20(4): 587-605.

Matejka, J. (2013). Internet jako objekt práva - Hledání rovnováhy autonomie a soukromí [Internet as the Object of Law - In Search of a Balance between Autonomy and Privacy]. Prague, CZ : CZ.NIC. 
Matuszak, Ł. \& Róźanska, E. (2017). CSR Disclosure in Polish-Listed Companies in the Light of Directive 2014/95/EU Requirements: Empirical Evidence. Sustainability, 9, 2304. DOI: https://doi.org/10.3390/su9122304.

McWilliams, A. \& Siegel, D. (2000) Corporate social responsibility and financial performance: Correlation or misspecification? Strategic Management Journal, 21(5): 603-609.

Meadows, D. H., Meadows, D.L., Randers, J., Behrens, W.W. (1972). The limtis to growth; Universe Books: New York, USA.

Morgan Stanley (2017). Millennials Drive Growth in Sustainable Investing. Morgan Stanley. Retrieved January 5, 2020 from https://www.morganstanley.com/ideas/sustainable-socially-responsibleinvesting-millennials-drive-growth.

Němečková, I. (2013). The Roles of Salary in Employee Motivation and Retention in the Financial Sector of the Czech Republic in Relation to Herzberg's Two Factor Theory of Work Motivation. Politická ekonomie, 61(3): 373-392.

Okoli, Ch. \& Pawlowski, S.D. (2004). The Delphi method as a research tool: an example, design considerations and applications. Information \& Management, 42(1): 15-29. DOI: https://doi.org/10.1016/j.im.2003.11.002

Olšanová, K., Gook, G. \& Zlatić, M. (2018). Influence of Luxury Companies' Corporate Social Responsibility Activities on Consumer Purchase Intention: Development of Theoretical Framework. Central European Business Review, 7(3): 1-25.

Osei-Tutu, J. J. (2019). Socially Responsible Corporate IP. FIU Legal Studies Research Paper Series. Research Paper No. 19-01.

Osterweil, W. (2012). The Sectret Shopper. The New Enquiry. Retrieved January 10, 2020 from https://thenewinquiry.com/the-secret-shopper/

Pakšiová, R. (2016). Understanding of corporate social responsibility in large companies in Slovakia within the context of sustainable development. In Economic policy in the European union member countries. International scientific conference. Karviná: School of Business Administration in Karvina, SU in Opava, 2016, pp. 516-525.

Pakšiová, R. (2017). Sustainability reporting in the Slovak republic. In Sustainability reporting in Central and Eastern European companies: international empirical insights. Cham: Springer, 143-154.

Pakšiová, R. \& Lovciová, K. (2019). Managerial Reporting by Food Production Companies in Slovakia in 2017. - Registrovaný v: Scopus. In Engineering Management in Production and Services. Kleosin : Bialystok University of Technology, 11(3): 71-85.

Petera, P., Wagner, J., Pakšiová, R. \& Krehnacová, A. (2019). Sustainability Information in Annual Reports of Companies Domiciled in the Czech Republic and the Slovak Republic. In Inzinerine Ekonomika-Engineering Economics. Kaunas : Kaunas University of Technology, 30(4): 483-495.

Peterson, L. (1983). Influence of age, task competence, and responsibility focus on children's altruism. Developmental Psychology, 19(1): 141. DOI: https://doi.org/10.1037/0012-1649.19.1.141.

Piekarczyk, A. (2016). Contemporary organization and a perspective on integration and development. Oeconomia Copernicana, 7(3): 467-483. DOI: https://doi.org/10.12775/OeC.2016.027.

Polcyn, J., Stępień, S. \& Czyżewski, B. (2019). The Measurement of the Quality of the Environment and its Determinants in Poland and in the Regional Perspective. Annales Universitatis Apulensis Series Oeconomica, 2019, 21(2): 11-21. DOI: https://doi.org/10.29302/oeconomica.2019.21.2.1

Porter, M. E. \& Kramer, M.R. (2011). Creating shared value. Harvard Business Review, 2011, 89(1/2):6267. 
Preston, L. E. \& O’Bannon, D.P. (1997). The corporate social-financial performance relationship. A typology and analysis. Business \& Society, 36, 419-429. DOI: https://doi.org/10.1177/000765039703600406.

Rodriguez-Fernandez, M. (2016). Social responsibility and financial performance. The role of good corporate governance. BRQ Business Research Quarterly, 19, 137-151. DOI: https://doi.org/10.1016/j.brq.2015.08.001.

Rowley, T. \& Berman, S. (2000). A brand new brand of corporate social performance. Business \& Society, 39(4): 397-418. DOI: https://doi.org/10.1177/000765030003900404.

Scherer, G. \& Palazzo, G. (2011). The new political role of business in a globalized world: A review of a new perspective on CSR and its implications for the firm, governance, and democracy. Journal of Management Studies, 48, 899-931. DOI: https://doi.org/10.1111/j.1467-6486.2010.00950.x

Schmidt, F.L. \& Hunter, J.E. (2014). Methods of Meta-Analysis - Correcting Error and Bias in Research Findings. $3^{\text {rd }}$ Edition, London, UK: SAGE.

Schüz, M. (2012). Sustainable Corporate Responsibility - The Foundation of successful Business in the New Millennium. Central European Business Review, 1(2): 7-15.

Sharfman, M. P. \& Fernando, Ch. S. (2008). Environmental risk management and the cost of capital. Strategic Management Journal, 29, 569-592. DOI: https://doi.org/10.1002/smj.678.

Silverman, D. (2013). Doing Qualitative Research - A Practical Handbook. $4^{\text {th }}$ Edition, London, UK: SAGE.

Sroka, W. \& Lörinczy, M. (2015). The perception of ethics in business: Analysis of research results. Procedia Economics and Finance, 34, 156-163. DOI: https://doi.org/10.1016/S22125671(15)01614-7.

Sroka, W. \& Szántó, R. (2018) Corporate Social Responsibility and Business Ethics in Controversial Sectors: Analysis of Research Results. Journal of Entrepreneurship, Management and Innovation - JEMI, 14, 111-126. DOI https://doi.org/10.7341/20181435.

Staníčková, M. \& Melecký, L. (2014). FACTORS DETERMINING DRIVING FORCES OF COMPETITIVENESS IN EU COUNTRIES. 12th International Conference on Hradec Economic Days (HED 2014): Economic Development and Management of Regions. Hradec Kralove: University Hradec Kralove, 338-348.

Strouhal, J., Gurvitš, N., Nikitina-Kalamäe, M. \& Startseva, E. (2015). Finding the link between CSR reporting and corporate financial performance: evidence on Czech and Estonian listed companies. Central European Business Review, 4(3), 48-59. DOI: https://doi.org/10.18267/j.cebr.132.

Svoboda, P. (2011). The Lisbon Treaty - From a Legal and Therefore Politically Incorrect Perspective. The Lawyer Quarterly, 1(2): 138-141.

Svobodová, M. (2016). On the Concept of Legislative Acts in the European Union Law. The Lawyer Quarterly, 4, 256-267.

Šebestová, J., Krejčí, P. \& Šiška, P. (2018). „Be or Not to Be“: A Dilemma of Business Policy Support on a Regional Level. Central European Business Review, 7(1):313. DOI: https://doi.org/10.18267/j.cebr.192

Thalassinos, E. \& Thalassinos, Y. (2018). Financial Crises and e-Commerce: How Are They Related. Retrieved January 5, 2020 from https://ssrn.com/abstract=3330169 and http://dx.doi.org/10.2139/ssrn.3330169 . DOI: https://doi.org/10.2139/ssrn.3330169. 
Ting, I. W. K., Azizan, N.A.; Bhaskaran, R. K. \& Sukumaran, S. K. (2019) Corporate Social Performance and Firm Performance: Comparative Study among Developed and Emerging Market Firms. Sustainability, 2019, 12, 26. DOI: https://doi.org/10.3390/su12010026.

Turečková, K. (2016). Sectoral specialization as a source of competitiveness: case study on ICT sector in V4+ countries. In: Proceedings of the 3rd International Conference on European Integration 2016. Ostrava: VŠB-TU Ostrava, pp. 1023-1029

Turečková, K. \& Nevima, J. The perils of drawing from European funds in public education. In: Public Administration 2016: Proceedings of the 11th International Scientific Conference. Pardubice: University of Pardubice, 2016, 273-283.

Tvrdoň, M. (2016). Decomposition of Unemployment: The Case of the Visegrad Group Countries. E\&M Ekonomie a Management, 19(1): 4-16.

Tvrdoň, M., Tuleja, P. \& Verner, T. (2012). Economic Performance and Labour Market in the Context of the Economic Crisis: Experience from the Visegrad Four Countries. E\&M Ekonomie a Management, 15(3): 16-31.

Vivant, M. (2016). Building a common culture IP? International Review of Intellectual Property and Competition Law, 47(3): 259-261. DOI: https://doi.org/10.1007/s40319-016-0472-y.

Vokoun, M. (2017). Characteristic of the innovation activities of firms in Europe: a critical review of international differences. Review of Economic Perspectives - Národohospodářský obzor, 17(3): 239-262. DOI: 10.1515/revecp-2017-0013.

Wanilin, A. (2006). The Lisbon Scorecard IV: Will Europe's Economy Rise Again? London: Center for European Reform.

World Commission on Environment and Development (1987). Our Common Future. Oxford university Press, New York, USA.

Yin, R. K. (2008). Study Research. Desing Methods. $4^{\text {th }}$ Edition. Thousand Oaks : Sage.

Zhao, Ch., Guo, Y., Yuan, J., Wu, M., Li, D., Zhou, Y. \& Kang, J. (2018). ESG and Corporate Financial Performance: Empirical Evidence From China's Listed Power Generation Companies. Sustainability, 10, 2607. DOI: https://doi.org/10.3390/su10082607.

The research paper passed the review process. | Received: January 14, 2020; Revised: March 27, 2020; Accepted: March 31, 2020; Published: July 10, 2020. 